\title{
Two new species of Grandidierella (Amphipoda, Corophiida, Aoridea) from Singapore
}

\author{
Alip ALI-EIMRAN ${ }^{1}$, Yen-ling LEE ${ }^{2}$ \& B.A. Rahim AZMAN ${ }^{3,4, *}$ \\ ${ }^{1,2}$ Tropical Marine Science Institute (TMSI), National University of Singapore, \\ 18 Kent Ridge Road, 119227, Singapore. \\ ${ }^{3}$ Marine Ecosystem Research Centre (EKOMAR), Faculty of Science and Technology, \\ Universiti Kebangsaan Malaysia 43600 Bangi, Selangor, Malaysia. \\ ${ }^{4}$ Department of Earth Sciences and Environment, Faculty of Science and Technology, \\ Universiti Kebangsaan Malaysia, 43600 UKM Bangi, Selangor, Malaysia. \\ *Corresponding author: abarahim@ukm.edu.my / abarahim@gmail.com \\ ${ }^{1}$ Email: tmsaea@nus.edu.sg \\ ${ }^{2}$ Email: tmsleeyl@nus.edu.sg

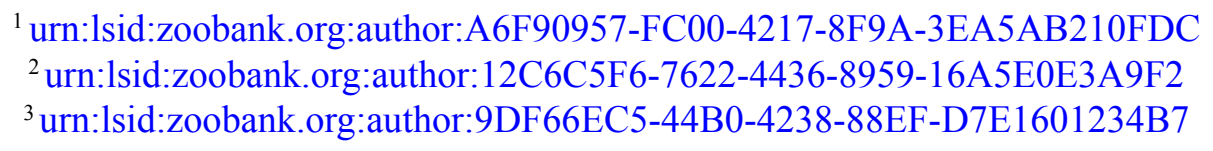

\begin{abstract}
Two new species of Grandidierella Coutière, 1904 from Singapore waters are described based on specimens collected during the Comprehensive Marine Biodiversity Survey (CMBS) between 2010-2015. Grandidierella pawaiensis sp. nov. differs from the rest in the genus by a combination of characters; (1) gnathopod 1 carpus proximoventral corner with apically acute process, (2) inner face of carpus of gnathopod 1 proximoventral corner with curved process, (3) proximal margin of dactylus of gnathopod 1 male with excavation, and (4) gnathopod 2 basis anterior margin crenulate. Grandidierella sungeicina sp. nov. on the other hand, is distinguishable from other related species of Grandidierella found in the tropical region by its paired mid-dorsal projections on pereonites 2 to 5,1 ventrodistal triangular projection on pereonite 4 , and gnathopod 2 ischium with 1 large trapezoid projection.
\end{abstract}

Keywords. Aoridae, Singapore, Grandidierella pawaiensis, Grandidierella sungeicina, new species.

Ali-Eimran A., Lee Y.-1. \& Azman B.A.R. 2020. Two new species of Grandidierella (Amphipoda, Corophiida, Aoridea) from Singapore. European Journal of Taxonomy 683: 1-28. https://doi.org/10.5852/ejt.2020.683

\section{Introduction}

In recent years, there have been efforts aimed at cataloguing the biodiversity of the fauna in Singapore. One such effort comes with the initiative of the Comprehensive Marine Biodiversity Survey (CMBS) carried out over a five-year period (2010-2015) jointly by the National Park's Board and the National University of Singapore's Tropical Marine Science Institute (NUS -TMSI). In relation to neighbouring countries, information on Singapore's marine biodiversity is still lacking and many regions and habitats 
remain insufficiently studied. To date, only 27 species of amphipods have been recorded from the coast of Singapore (Stebbing 1887; Mayer 1903; Lowry 2000; Azman \& Alip 2015; White 2015). As one of the busiest entrepôt countries in the world, Singapore's waters are known to be a complex zone where ecological and human interaction have a dramatic impact on the marine biodiversity. The survey expanded the scope of habitats sampled to include a range of shallow and deep benthic habitats comprising hard and soft benthic types around Singapore in order to establish a reliable baseline to guide future coastal development, conservation, and rehabilitation, as well as to build local capacity and widen the appreciation of the marine biodiversity. It is therefore of high priority to improve descriptions of numerous taxonomic groups and to expand our knowledge of their geographical distributions. In the present contribution, we describe two new species of Grandidierella Coutière, 1904. These species represent the first Singapore records of the genus.

\section{Material and methods}

Grandidierella pawaiensis sp. nov. was collected in August 2012 from the northern part of Pulau Pawai (Fig. 1) at GPS point $01^{\circ} 11.336^{\prime} \mathrm{N}, 103^{\circ} 43.372^{\prime} \mathrm{E}$ by random sampling at a tidal height of $1.1 \mathrm{~m}-1.4 \mathrm{~m}$ above Chart Datum (CD). Grandidierella sungeicina sp. nov. was collected from the Sungei Cina river mouth, in a mudflat environment at GPS point $01^{\circ} 26.969^{\prime} \mathrm{N}, 103^{\circ} 43.696^{\prime} \mathrm{E}$ in January 2011 , via transect sampling within a rectangle of $50 \mathrm{~m}$ by $10 \mathrm{~m}$, at a tidal height of $0.9 \mathrm{~m}-1.3 \mathrm{~m}$ above $\mathrm{CD}$, parallel to the waterline.

Sediments from both locations were washed in situ through a $2 \mathrm{~mm}$ mesh before specimens were brought back to the laboratory for sorting and identification using an Olympus SZX10 light stereo microscope. Grandidierella pawaiensis sp. nov. was first fixed in $2 \%$ buffered formalin before being stored in $75 \%$ denatured ethanol while G. sungeicina sp. nov. was preserved directly in $75 \%$ denatured ethanol. Specimens were transferred from $75 \%$ ethanol into increasing concentrations of glycerol before being dissected. Individual appendages were then mounted on a glass slide in glycerol.

Illustrations were done using a camera lucida system mounted on an Olympus BX50 light compound microscope before being digitally 'inked' following Coleman (2003). The terminology for cuticle projections (spines and setae) follows Watling (1989). Type material is deposited at the Lee Kong Chien Natural History Museum, National University Singapore (LKCHM NUS), Singapore.

\section{Abbreviations}

The following abbreviations are used:
$\mathrm{A}=$ antenna
$\mathrm{bl}=$ body length
$\mathrm{EP}=$ epimeron
$\mathrm{G}=$ gnathopod
$\mathrm{HD}=$ head
$\mathrm{L}=$ left
LL = lower lip
$\mathrm{MD}=$ mandible
$\mathrm{MX}=$ maxilla
MXP $=$ maxilliped
$\mathrm{P}=$ pereopod
$\mathrm{R}=$ right
$\mathrm{T}=$ telson
$\mathrm{U}=$ urosomite
$\mathrm{UL}=$ upper lip
UR = urosome 


\section{Results}

\section{Taxonomy}

Order Amphipoda Latreille, 1816

Infraorder Corophiida Leach, 1814

Family Aoridae Stebbing, 1899

Genus Grandidierella Coutière, 1904

\section{Diagnosis}

Eyes small to medium. Accessory flagellum of antenna 1 minute, uniarticulate. Inner plate of maxilla one vestigial. Coxae very small, relatively short, of various sizes and shapes. Gnathopod 1 (male) complexly subchelate and much larger than gnathopod 2. Gnathopod 2 subchelate. Dactylus of pereopods 6 and 7 elongate; falcate. Uropods 1 and 2 biramous; rami slightly subequal; peduncle with ventrodistal process. Uropod 3 uniramous. Telson entire.

\section{Type species}

Grandidierella mahafalensis (Coutière, 1904).

\section{Species composition}

Grandidierella includes 46 species: G. africana Schellenberg, 1936; G. bispinosa Schellenberg, 1938; G. bonnieroides Stephensen, 1947; G. cabindae (Schellenberg, 1925); G. chaohuensis Hou \& Li, 2002;

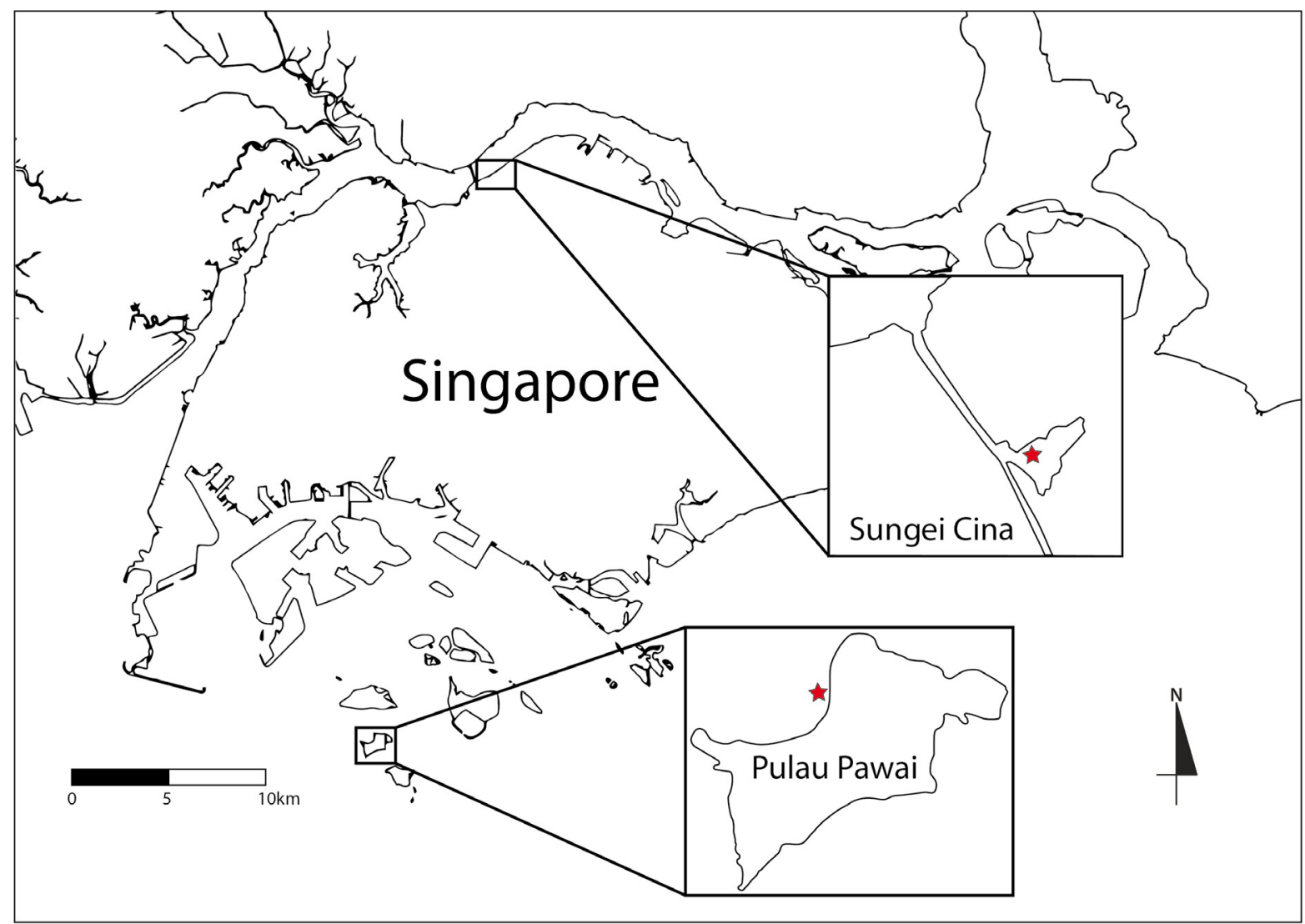

Fig. 1. Map of Singapore with locations of collecting sites: Sungei Cina and Pulau Pawai. 
G. chelata K.H. Barnard, 1951; G. dentimera Myers, 1970; G. elongata (Chevreux, 1926); G. exilis Myers, 1981; G. fasciata Ariyama, 1996; G. gilesi Chilton, 1921; G. gravipes K.H. Barnard, 1935; G. grossimana Ledoyer, 1967; G. halophilus Wongkamhaeng, Pholpunthin \& Azman, 2012; G. indentata Ledoyer, 1979; G. insulae Myers, 1981; G. ischienoplia Bochert \& Zettler, 2010; G. japonica Stephensen, 1938; G. kanakensis Myers, 1981; G. koa J.L. Barnard, 1977; G. lignorum K.H. Barnard, 1935; G. longidactylus Ledoyer, 1983; G. lutosa K.H. Barnard, 1952; G. macronyx K.H. Barnard, 1935; G. mahafalensis Coutière, 1904; G. makena (J.L. Barnard, 1970); G. megnae Giles, 1888; G. melakaensis Azman \& Othman, 2012; G. nioensis A.A. Myers, 2019; G. nottoni Shoemaker, 1935; G. nyala (Griffiths, 1974); G. osakaensis Ariyama, 1996; G. palama J.L. Barnard, 1977; G. perlata Schellenberg 1938; G. phetraensis Wongkamhaeng, Coleman \& Pholpunthin, 2013; G. propodentata Morre, 1986; G. rhizophorae Myers, 2009; G. robusta Ledoyer, 1983; G. rubroantennata Ariyama \& Taru, 2017; G. sanrikuensis Ariyama \& Taru, 2017; G. spinicoxa Myers, 1972; G. taihuensis Morino \& Dal, 1990; G. teres Myers, 1981; G. trispinosa Bano \& Kazmi, 2010; G. unidentata Ren, 2006; G. vietnamica Dang, 1968.

Grandidierella pawaiensis sp. nov. urn:1sid:zoobank.org:act:F43BC745-2E46-4FB7-A993-FF242683C420

Figs 2-10

\section{Etymology}

This species is named after the type locality, Pulau Pawai, Singapore.

\section{Material examined}

Holotype

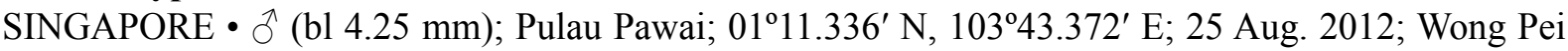
San Helen, Lee Yen-ling, Ria Tan, Toh Chay Hoon, Tay Ywee Chieh and Chen Chia Xin leg.; shallow water muddy bottom; ZRC 2018.0493.

\section{Paratypes}

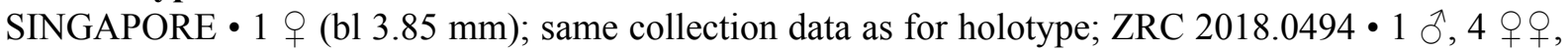
1 juv.; same collection data as for holotype; ZRC 2018.0495.

\section{Type locality}

Pulau Pawai, Singapore.

Description (based on the holotype $\widehat{\partial}$, ZRC 2018.0493)

BoDy. Subcylindrical.

HEAD. Eyes present and well developed, set just posterior to margin of lateral lobe. Epimeral plate 3 about 1.4 times as long as 1 or 2 . Head as deep as long, longer than pereonite 1; anteroventral margin moderately excavate, corner sharp.

ANTENNA 1 (Fig. 3A1). Peduncular articles 1-3 with ratio of 4:5:2; article 1 margins slightly convex with clump of slender setae near ventrodistal corner; article 2 slender, dorsal and ventral margins lined with slender setae; article 3 short, accessory flagellum present, uniarticulate, apically acute, half the length of flagellar article 1 with long slender apical setae; flagellum with at least 11 articles, distal margin of each article possessing short slender setae. 
AntenNa 2 (Fig. 3A2). Shorter and more robust than 1; peduncular articles combined length twice as long as flagellum; peduncular articles 3-5 with length in ratio 2:5:5; peduncular article 1 subquadrate, ventrodistal corner with long slender and 1 robust setae; article 2 ventral margin with short to long slender setae; article 3 slender, margins with slender setae; flagellum with 8 articles, distal margin of each fringed with slender setae, articles 6-8 with robust setae on ventrodistal margin, article 8 distally tapering.

UPPER LIP (Fig. 4UL). Broader than long, margin covered in short fine setae, distal margin prepubescent.

LOWER LIP (Fig. 4LL). Outer lobe entire margin covered in fine setae, medial margins prepubescent, distomedial corner with arborescent setae, distal margin possessing one plumose apical setae; mandibular lobe blunt, distally possessing short setae.

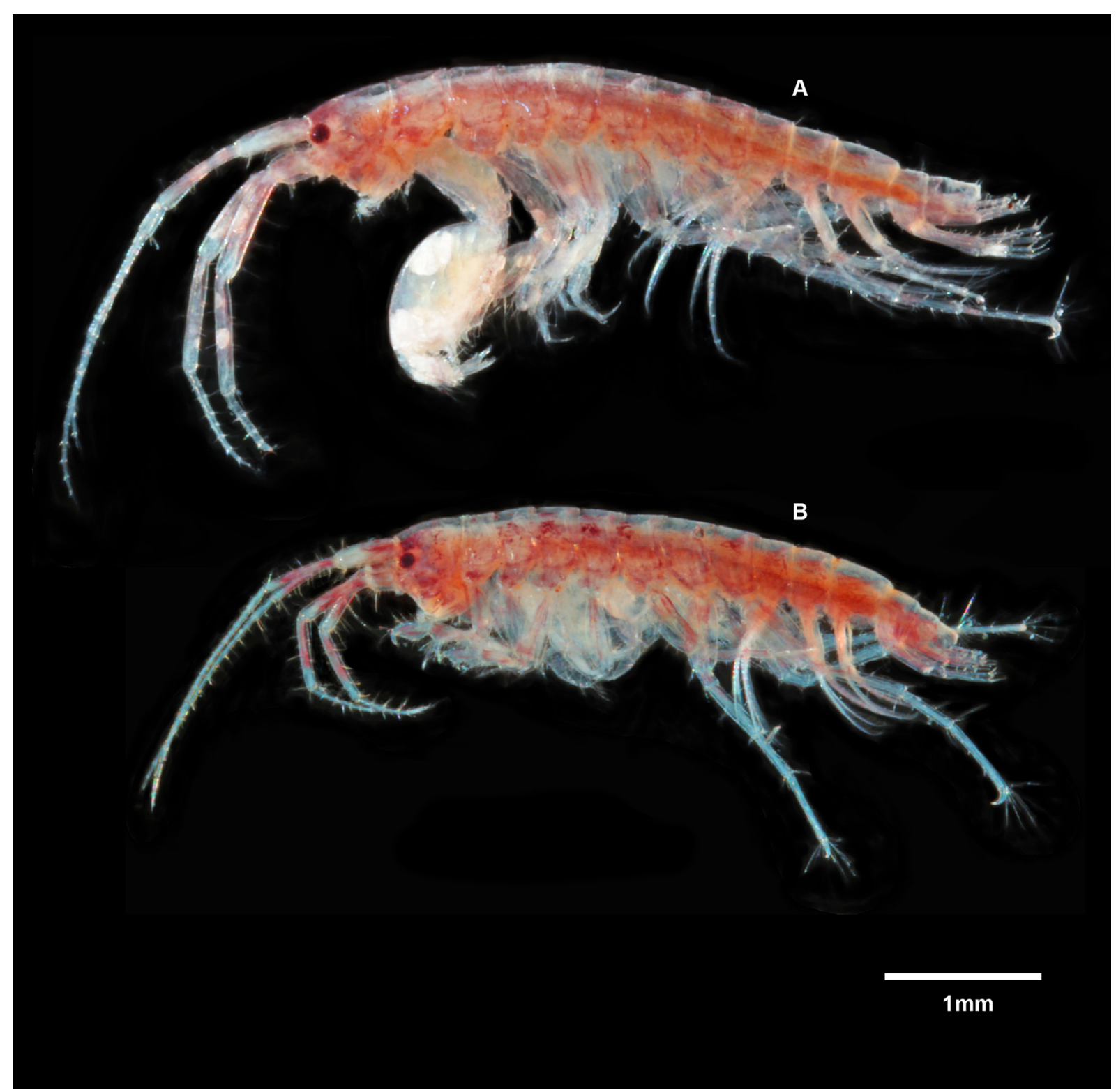

Fig. 2. Grandidierella pawaiensis sp. nov. A. Holotype, $\overbrace{}^{\Uparrow}$, lateral view (ZRC 2018.0493). B. Allotype,, , lateral view (ZRC 2018.0494). 


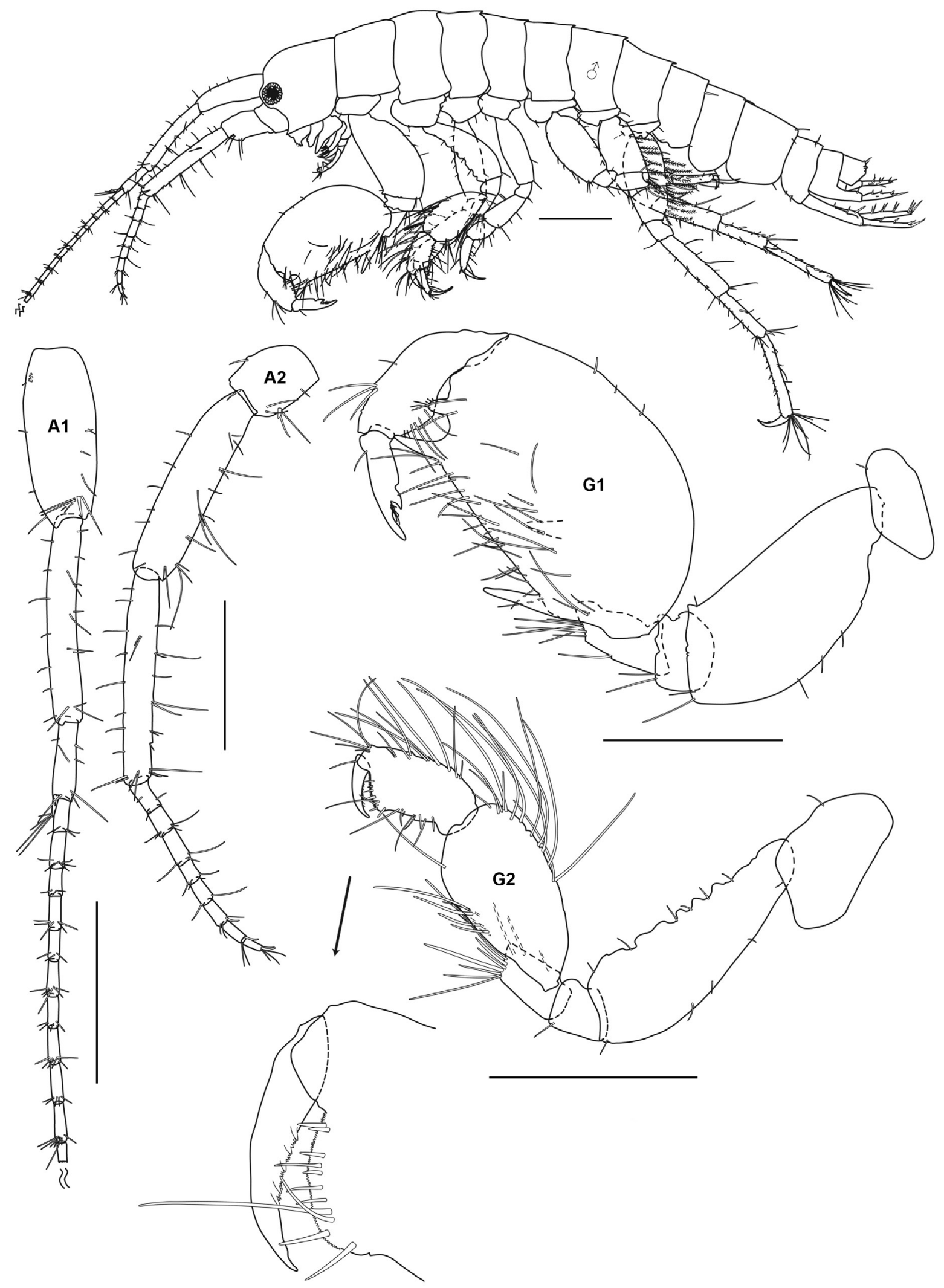

Fig. 3. Grandidierella pawaiensis sp. nov., holotype, $\widehat{\partial}$ (ZRC 2018.0493). Scale bars: $0.5 \mathrm{~mm}$. 
MANDiBLes (Fig. 4MD). Well developed, subtriangular; incisors each with 4 teeth; lacinia mobilis on left mandible with 4 teeth, right mandible with 2 teeth; spinal row armed with 6 processes; molar process well developed, rounded; palp triarticulate, article 1 shortest with article 3 longest; article 2 laterodistal margin slightly expanded, article 3 linguiform, apically rounded, lateral margin with long slender setae, left mandible apical and comb setae plumose, right mandible apical setae plumose, comb setae slender.

MAXILLA 1 (Fig. 4MX1). Inner lobe vestigial; outer lobe distally truncate with 8 apical denticulate setae, proximolateral margin with fine setae; palp biarticulate; article 10.3 times as long as article 2; article 2 linguiform, distally rounded with 6 apical robust setae and 4 subapical setae, distolateral margin with 3 slender setae.

MaXILla 2 (Fig. 4MX2). Inner lobe subequal in length to outer lobe; inner lobe medial and lateral margins slightly convex, deep face covered in short setae, medial margin possessing long plumose setae; outer lobe lateral and medial margins straight, slightly distally expanded, lateral margin with short setae, distal end rounded with mixture of long slender and plumose setae.

MAXILLIPED (Fig. 4MXP). Inner lobe distally truncate, extending slightly beyond article 1 of palp, lateral margin with fine setae, medioproximal margin with long robust setae, mediodistal margin with 8-10 slender setae and 4 apically oblique processes; outer lobe almost reaching end of article 2 of palp, apically rounded with long robust setae, lateral margin convex and with fine setae, medial margin straight with robust setae and submarginal slender setae; palp 4-articulate, article 2 medial margin with long slender setae, article 3 distal margin covered in long slender setae with 1-2 serrate setae, article 4 subtriangular ending in a stout spine.

GNATHOPOD 1 (Fig. 3G1). Enlarged, more robust than 2, carpochelate; coxa small, anterodistally unproduced; basis posteriorly expanded, ventrodistal corner with slender setae; ischium subquadrate, ventrodistal corner with slender setae; merus not anterodistally produced, sparsely setaceous along distal margin; carpus enlarged, twice as long as propodus; dorsal margin convex, ventral margin straight, entire margin with slender setae, proximoventral corner with apically acute process, inner midface possessing apically acute process, anteroventral corner with 2 processes forming a broad excavate sinus; propodus posterodistal margin slightly expanded, fringed with slender setae; dactylus less than half length of propodus with notch $2 / 3$ of the way up ventral margin.

GNATHOPod 2 (Fig. 3G2). Smaller than 1, subchelate; coxa subquadrate; basis distally expanded, anterodistal margin without flange, anterior margin crenulate; ischium subquadrate; merus with long setae on distal margin; carpus obovate, longer than propodus, dorsal margin moderately setose with long slender setae midway up margin, ventral margin with slender setae mid-margin; propodus dorsal and ventral margins parallel, dorsal margin with long slender setae, ventral margin with shorter slender setae, palm serrulate with a row of sub-marginal robust setae; dactylus curved, half the length of propodus, ventral margin doubly serrate.

PEREOPOD 3-4 (Fig. 5P3-P4). Coxae subquadrate; basis slightly expanded; ischium subquadrate; merus distally expanded, dorsodistal margin with a pair of long robust setae, dorsal and ventral margins sparsely setaceous; carpus subovate; propodus elongate, longer than carpus, dorsal and ventral margins sparsely setaceous; dactylus falcate.

PEREOPOD 5 (Fig. 5P5). Shortest; coxa posteriorly expanded into a tapering apically blunt process; basis with robust setae along anterior margin; ischium subquadrate; merus anterior margin with slender setae, anterodistal corner with a pair of long robust setae, posterodistal corner with 1 robust setae; carpus anterior margin with 3 robust setae, posterior margin with 3 short robust setae; propodus slender, with 4 


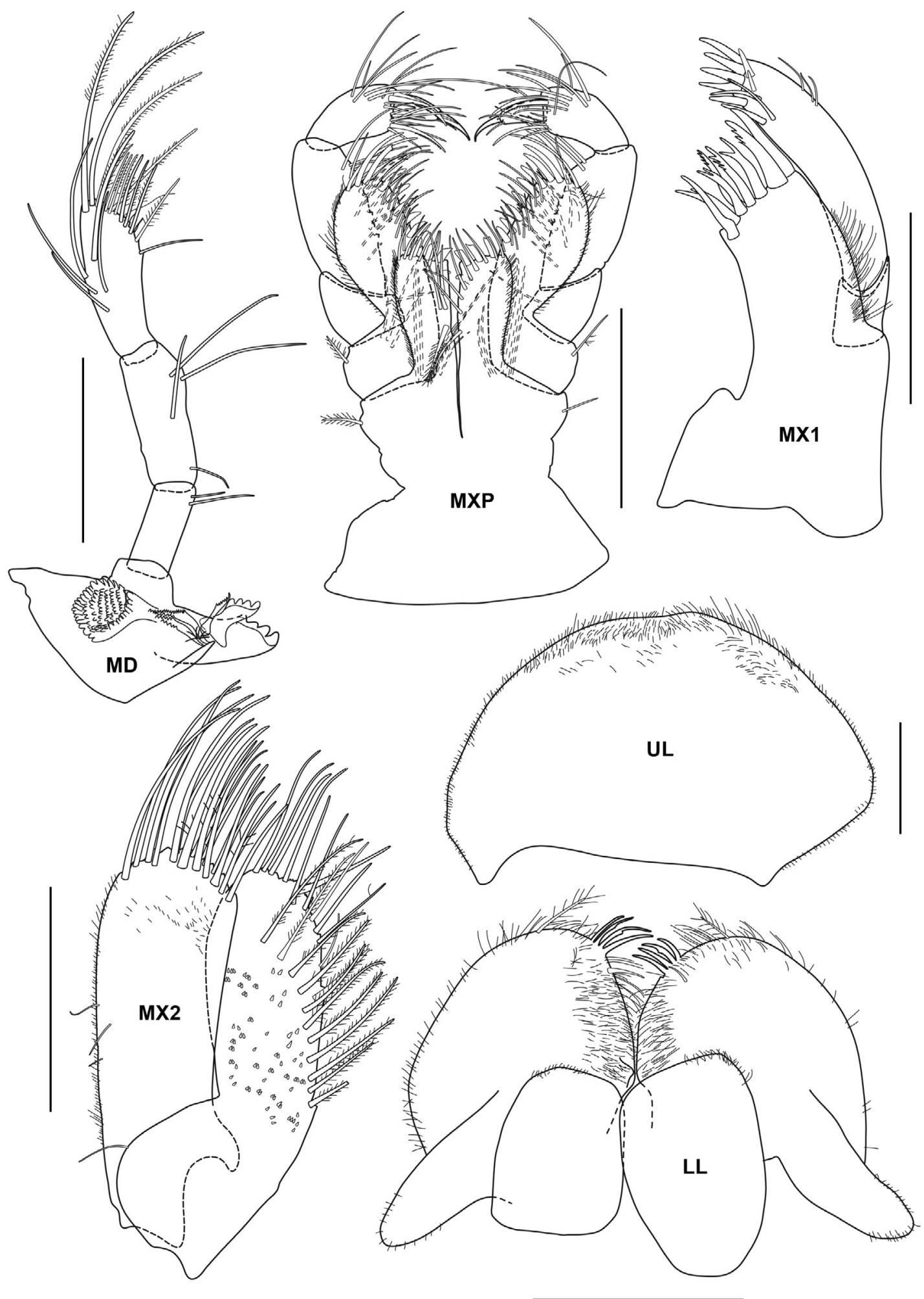

Fig. 4. Grandidierella pawaiensis sp. nov., holotype, $\widehat{\partial}$ (ZRC 2018.0493). Scale bars: $\mathrm{UL}=0.05 \mathrm{~mm}$; $\mathrm{MD}, \mathrm{MXP}=0.2 \mathrm{~mm}$; remaining scales $=0.1 \mathrm{~mm}$. 


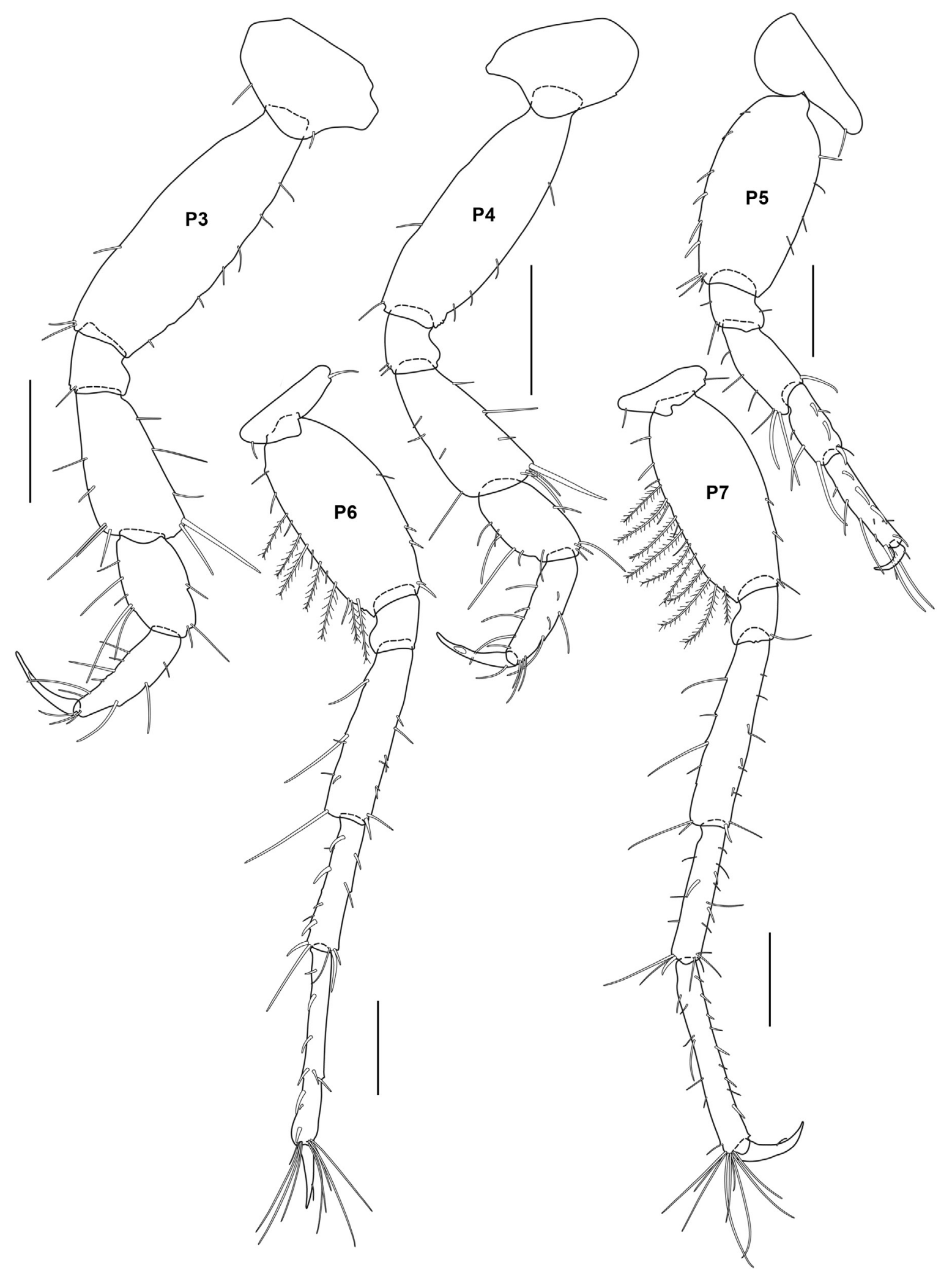

Fig. 5. Grandidierella pawaiensis sp. nov., holotype, ổ (ZRC 2018.0493). Scale bars: $0.25 \mathrm{~mm}$. 
short to long robust setae along anterior margin and 4 short robust setae along posterior margin; dactylus falcate.

PEREOPOD 6-7 (Fig. 5P6-P7). Pereopod 6 shorter than 7; coxa small, anterodistally expanded into a tapering apically blunt process; basis posterior margin with plumose setae, anterior margin possessing short robust setae; ischium subquadrate; merus slightly expanded posterodistally, posterior margin with 3 long slender setae, anterior margin with short setae; carpus slender, anterior margin with short slender setae, posterior margin with 1-4 robust setae, posterodistal corner with long robust setae; propodus slender, ventrodistal corner possessing long slender setae; dactylus falcate.

UROPOD 1 (Fig. 6U1). Biramous, peduncle longer than rami, inner and outer rami subequal in length; peduncle lateral margin with 5 robust setae, medial margin with 4 robust setae, interramal spine present and shorter than peduncle; outer ramus with 3 robust setae on outer margin, apice with 4 robust setae.

UROPOD 2 (Fig. 6U2). Biramous, peduncle subequal in length to inner ramus, outer ramus longer than inner ramus; peduncle lateral and medial margins with 2 robust setae; outer ramus lateral margin with 3 robust setae, medial margin with 2 robust setae, apice with 5 robust setae; inner ramus with 4 apical setae.

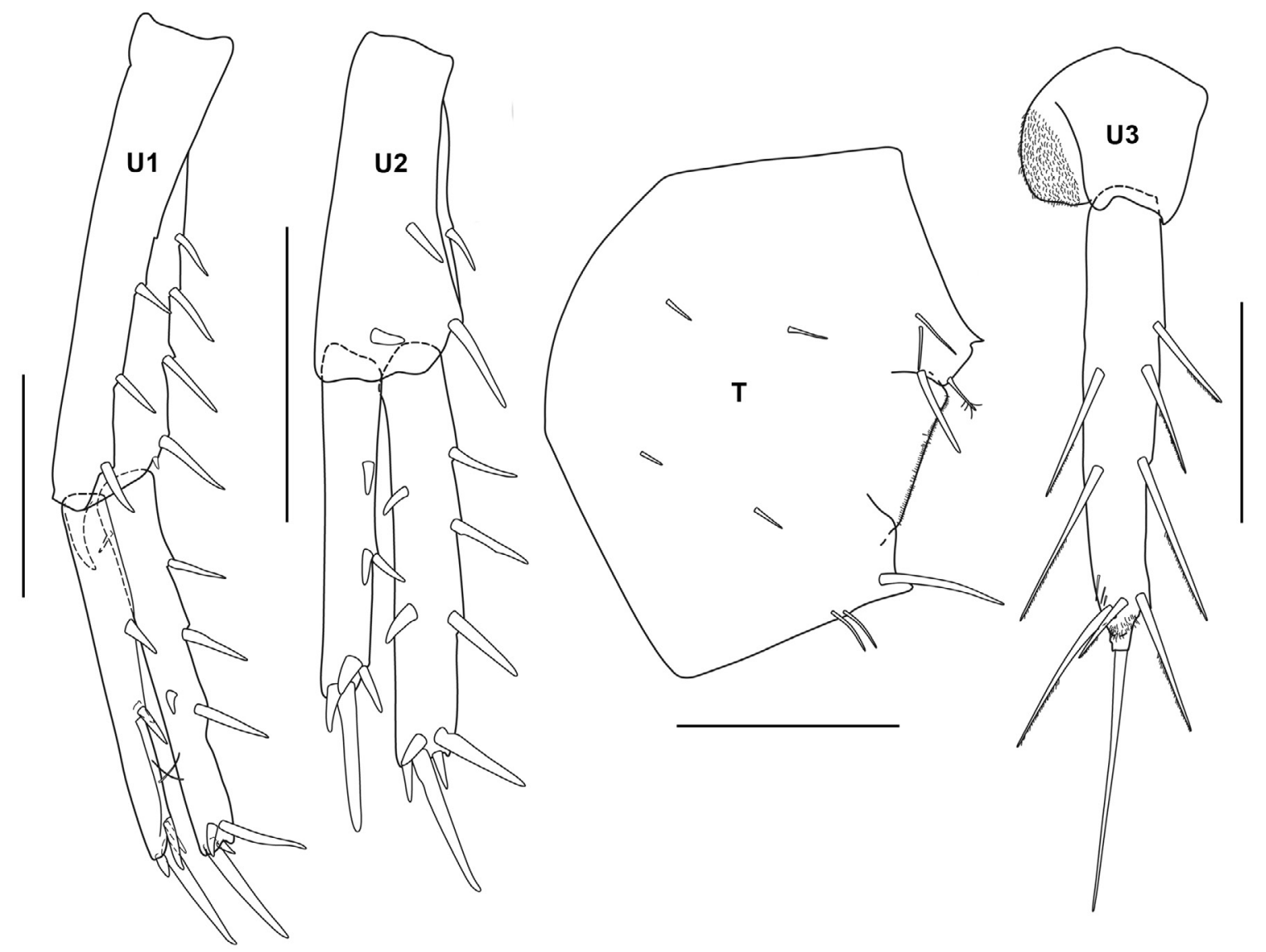

Fig. 6. Grandidierella pawaiensis sp. nov., holotype, $\widehat{\jmath}$ (ZRC 2018.0493). Scale bars: U3 = $0.1 \mathrm{~mm}$; remaining scales $=0.2 \mathrm{~mm}$. 


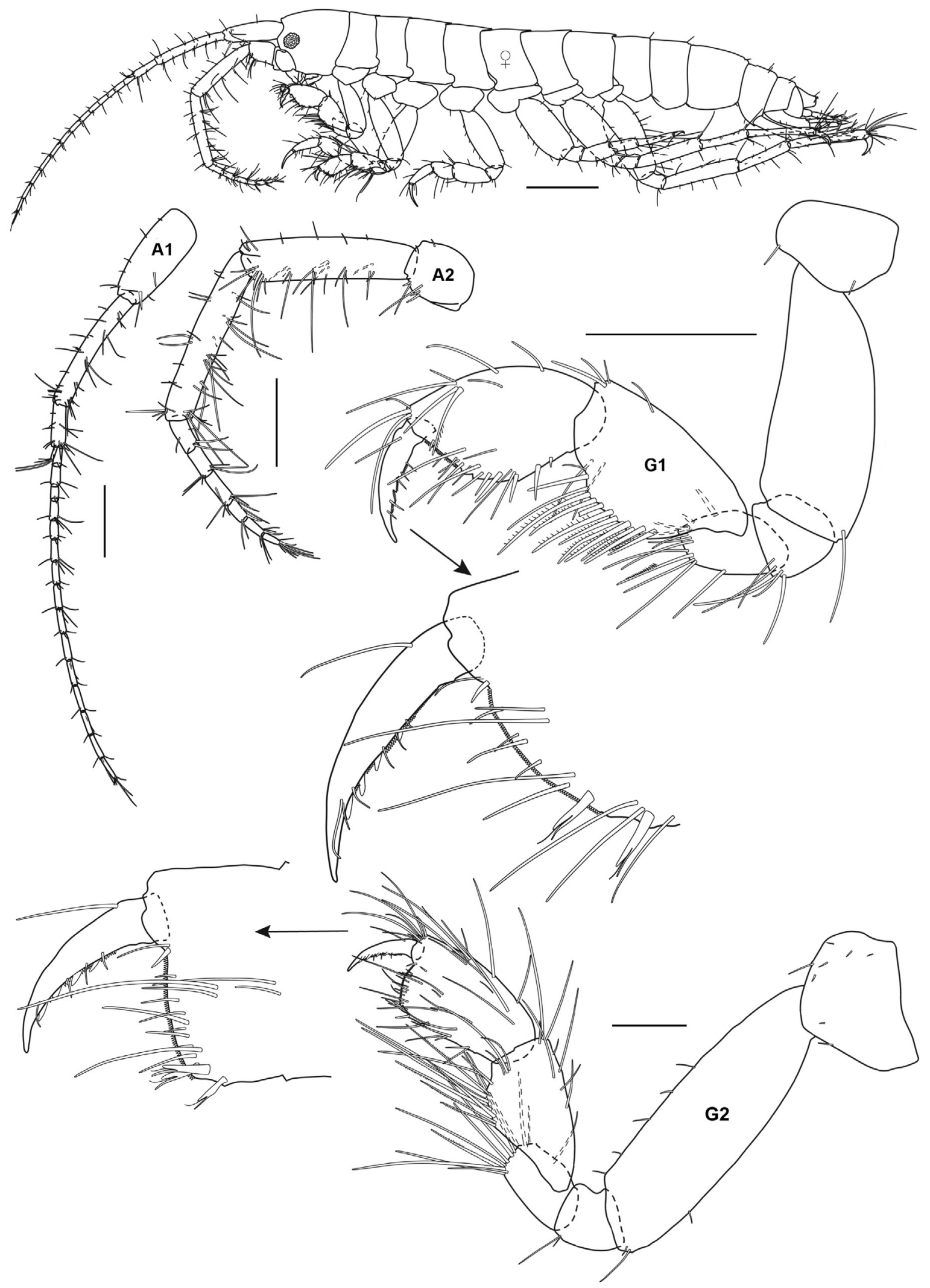

Fig. 7. Grandidierella pawaiensis sp. nov., allotype, $q$ (ZRC 2018.0494). Scale bars: $0.25 \mathrm{~mm}$. 


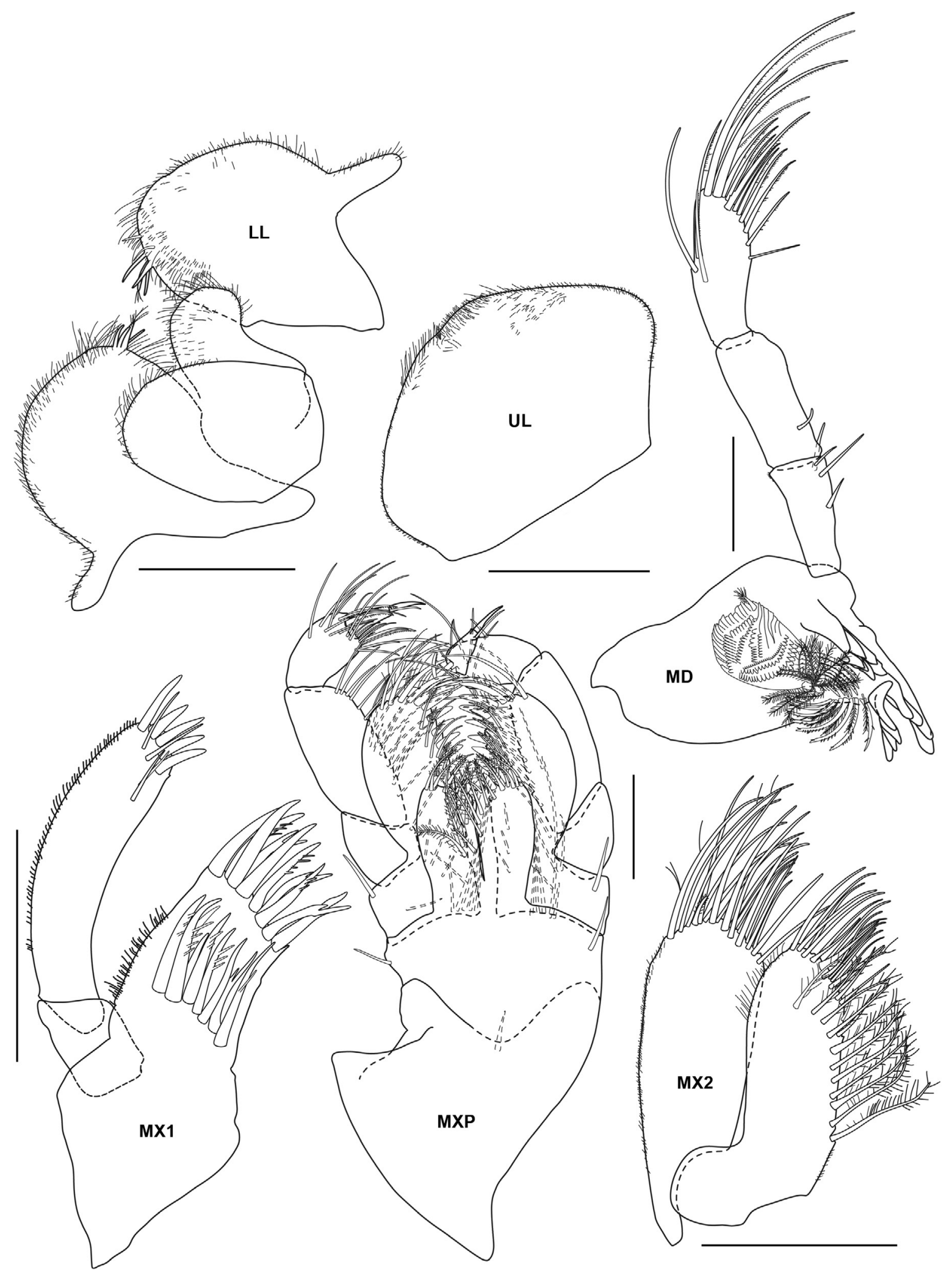

Fig. 8. Grandidierella pawaiensis sp. nov., allotype, + (ZRC 2018.0494). Scale bars: $0.1 \mathrm{~mm}$. 


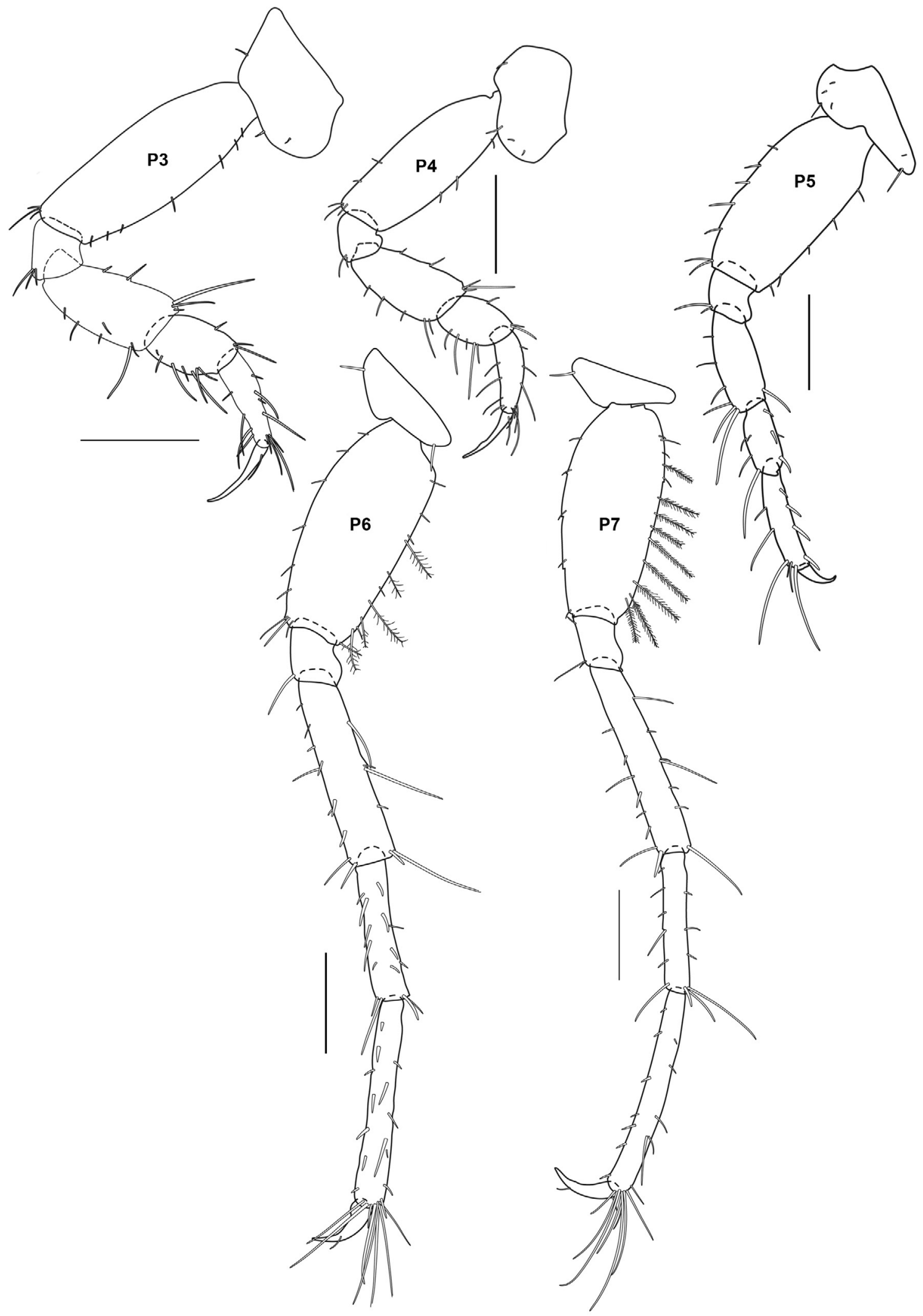

Fig. 9. Grandidierella pawaiensis sp. nov., allotype, $q$ (ZRC 2018.0494). Scale bars: $0.25 \mathrm{~mm}$. 
UROPOD 3 (Fig. 6U3). Uniramous, ramus 3 times longer than peduncle; peduncle broader than long, outer lobe covered in short fine setae; ramus long, medial margin with 3 long serrate setae, lateral margin with 2 long serrate setae, distal end with 1 long apical setae and 3 long subapical serrate setae.

TeLson (Fig. 6T). Rhomboidal, broader than long, apically truncate, superior face with 4 short setae, distal margin with short fine setae, distolateral margins with long robust setae.

Female (dimorphic characters; based on the paratype $q$, ZRC 2018.0494)

GNATHOPOD 1 (Fig. 7G1). Subchelate, smaller than male; merus distal margin with one serrate setae; carpus ventrally expanded, with row of serrate setae on ventral margin; propodus subequal in length to carpus, obovate, palm serrate; dactylus about 0.75 times as long as propodus, palm serrate, defined by strong posterodistal spine; dactylus ventral margin doubly serrate.

GNATHOPOD 2 (Fig. 7G2). Basis anterior margin straight; carpus ventrally expanded with long serrate setae. Additional illustrations (Figs 8-10) are also provided for future reference.
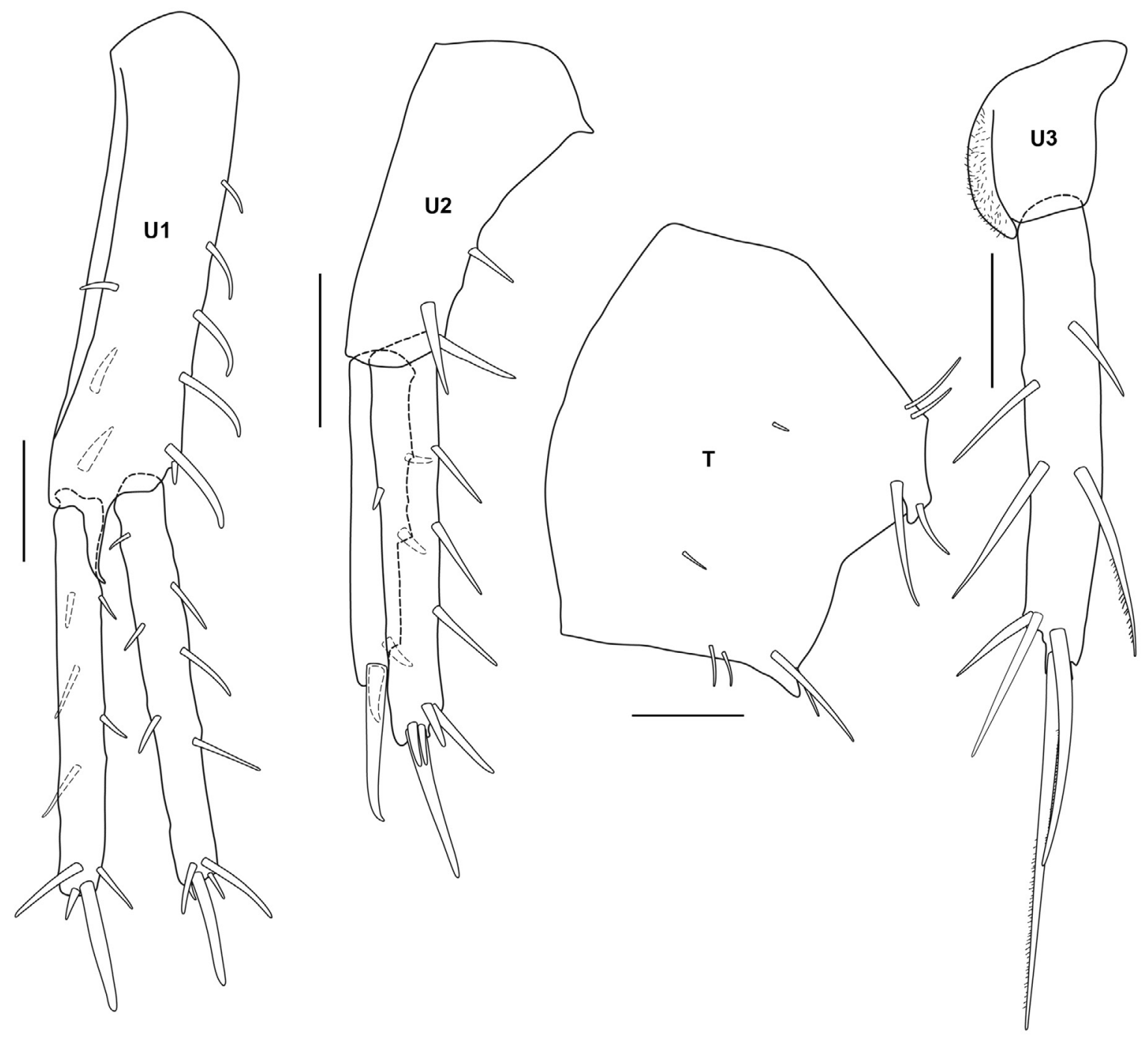

Fig. 10. Grandidierella pawaiensis sp. nov., allotype, $\uparrow$ (ZRC 2018.0494). Scale bars: U1-U2 =0.1 mm; $\mathrm{U} 3, \mathrm{~T}=0.05 \mathrm{~mm}$. 


\section{Remarks}

Grandidierella pawaiensis sp. nov. is closely similar to G. bispinosa. However, the new species possesses a mixture of features that differ from the specimens collected from the Bismarck Archipelago (Schellenberg 1938), the Moluccas (Ledoyer 1979) and Fiji (Myers 1981). Differences between specimens are mainly seen on gnathopods 1 and 2. For gnathopod 1, the dorsal margin of the carpus is more dorsally rounded, similar to the specimens collected from the Moluccas and Fiji. There is also the absence of 2 denticles on the ventromedial margin of the carpus as seen in Myers' specimen. The anterior margin of gnathopod 2 is distinctly more crenulate in the present material.

Grandidierella sungeicina sp. nov.

urn:lsid:zoobank.org:act:B5983965-F7CF-4F6A-94D9-BE0385CFF094

Figs 11-19

\section{Etymology}

This species is named after the type locality, Sungei Cina, Singapore.

\section{Material examined}

\section{Holotype}

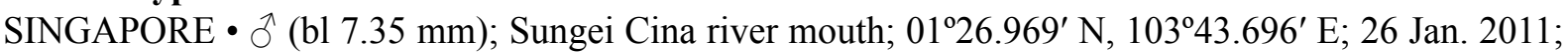
CMBS staff and volunteers leg.; shallow water muddy bottom; ZRC 2018.0490.

\section{Paratypes}

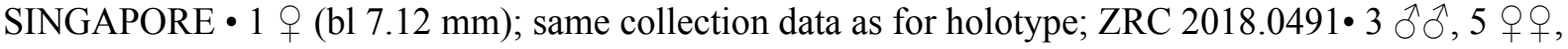
4 juvs; same collection data as for holotype; ZRC 2018.0492.

\section{Type locality}

Sungei Cina, Singapore.

Description (based on the holotype ô, ZRC 2018.0490)

Body. Subcylindrical.

HEAD. Longer than deep, longer than pereonites 1 and 2 combined, anteroventral margin moderately excavate. Eyes present and well developed, set just posterior to margin of lateral lobe. Epimeral plate 3 longer than 1 or 2 .

ANTENNA 1 (Fig. 12A1). Longer than 2; weakly setiferous; peduncular articles 1-3 with ratio of 5:7:2; peduncular article 1 with robust setae on ventral margin; peduncular article 2 slender; peduncular article 3 shorter than 1 or 2; accessory flagellum present, minute, uniarticulate, apically rounded; flagellum consisting of 17 articles, each article distally fringed with fine setae.

ANTENNA 2 (Fig. 12A2). More robust than 1; peduncular articles 3-5 with ratio of 1:3:2; flagellum 4-articulate, distally fringed with slender setae, articles 3-4 possessing robust setae on ventral margin.

UPPER LIP (Fig. 13UL). Broader than long, apically truncate, distal margin prepubescent.

LOWER LIP (Fig. 13LL). Inner lobe smaller than outer lobe with short setae on distal margin; outer lobe longer than broad, distal margin rounded and with fine setae, distomedial margin with a pair of short blunt processes. 
MANDiBLES (Fig. 13MD). Well developed, subtriangular; left incisor with 5 teeth, right with 4; lacinia mobilis with 4 teeth on both right and left sides; left mandible armed with 6 accessory blades, right mandible with 9 accessory blades; molar process well developed, rounded; palp well developed, triarticulate; article 1 with fine setae on proximolateral corner and long setae on distal margin, article 2 slender with long setae throughout entire length, article 3 spatulate with long setae throughout entire length, subapical setae plumose, apical setae serrate.

MAXILLA 1 (Fig. 13MX1). Inner lobe vestigial, outer lobe distally truncate, medioproximal corner with a clump of slender setae, distal margin with 8 spinulate setae, laterodistal margin with fine setae; palp biarticulate, article 10.3 times as long as article 2 , article 2 broadening distally, laterodistal margin with

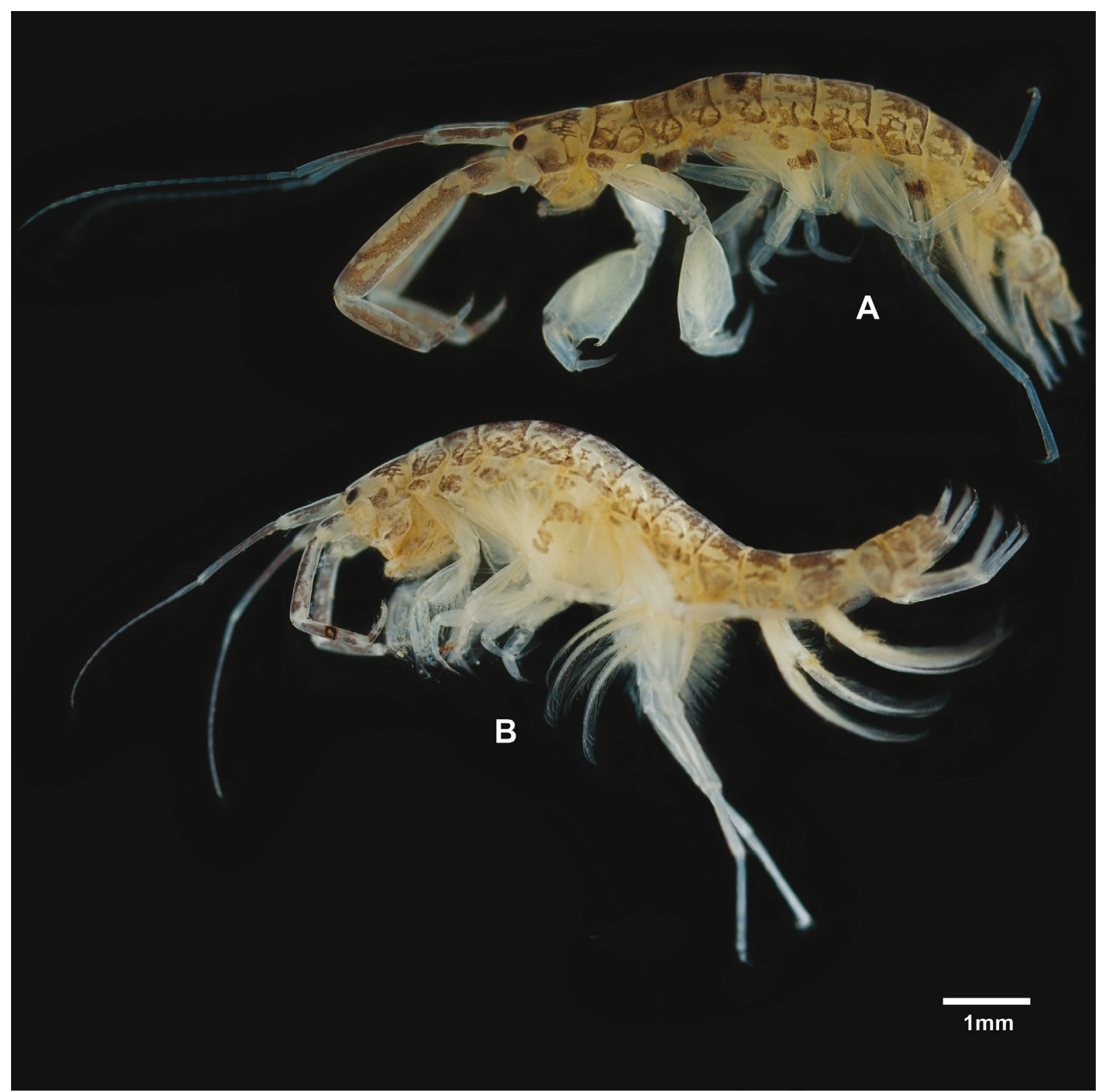

Fig. 11. Grandidierella sungeicina sp. nov. A. Holotype, đ̂, lateral view (ZRC 2018.0490). B. Allotype, +, lateral view (ZRC 2018.0491). 


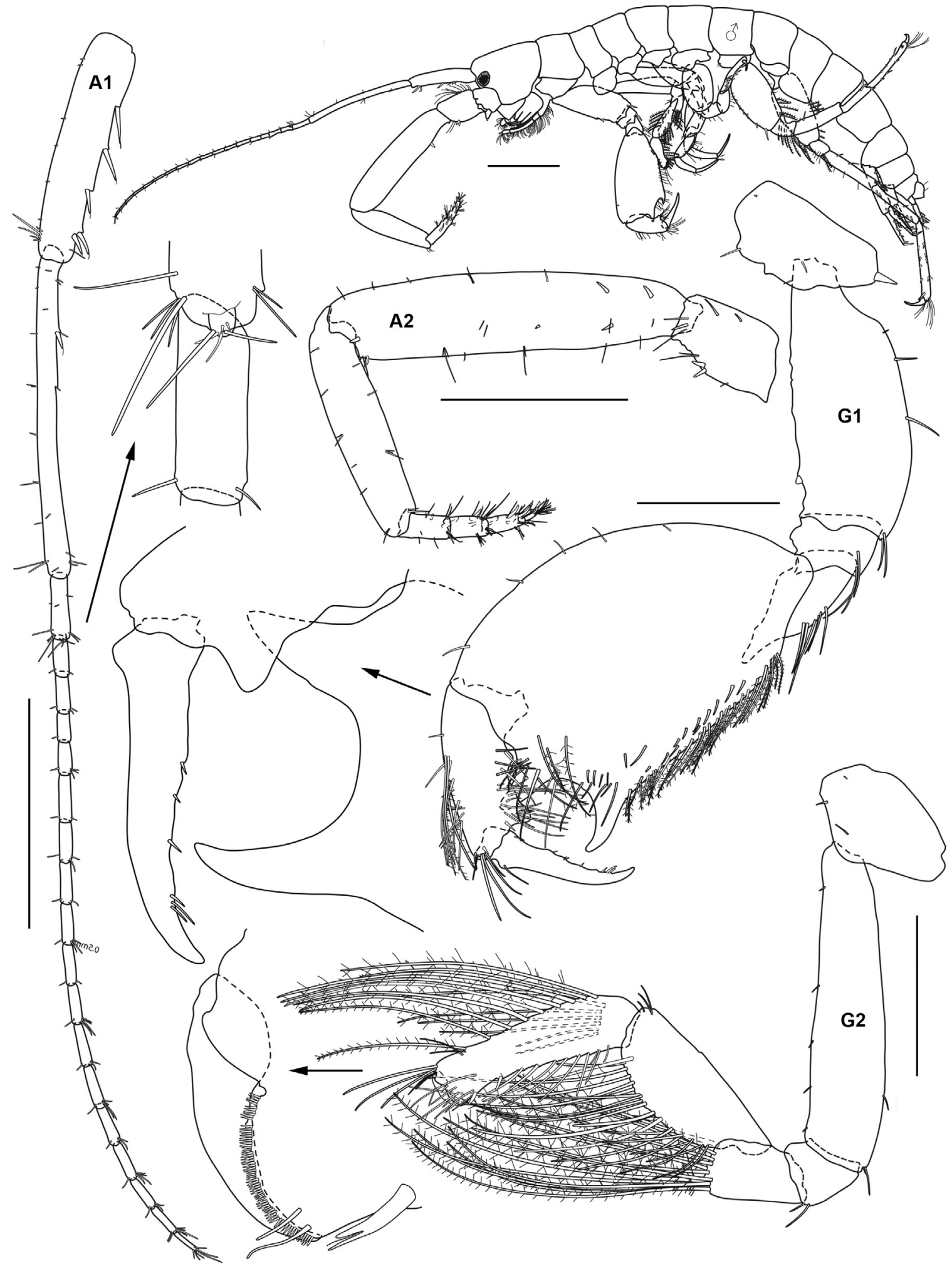

Fig. 12. Grandidierella sungeicina sp. nov., holotype, $\widehat{\partial}$ (ZRC 2018.0490). Scale bars: A1, A2 =0.1 mm; remaining scales $=0.5 \mathrm{~mm}$. 


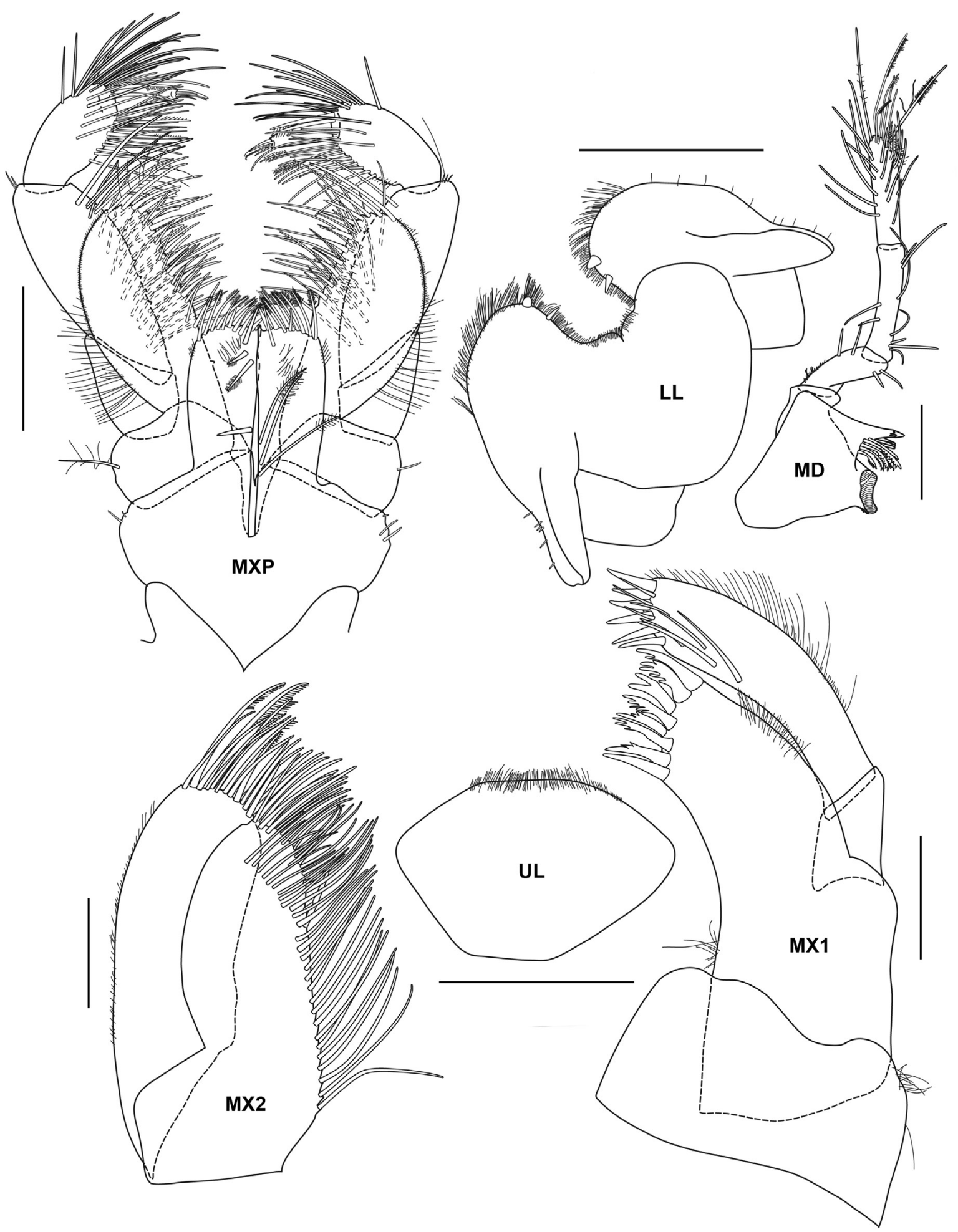

Fig. 13. Grandidierella sungeicina sp. nov., holotype, $\widehat{\partial}$ (ZRC 2018.0490). Scale bars: $\mathrm{MXP}=0.2 \mathrm{~mm}$; $\mathrm{UL}, \mathrm{LL}=0.25 \mathrm{~mm}$; remaining scales $=0.1 \mathrm{~mm}$. 
a row of fine setae, distal margin with apical robust setae, distomedial margin with long sub-marginal setae.

MAXILLA 2 (Fig. 13MX2). Both lobes apically rounded; inner lobe shorter than outer lobe, lateral margin convex, medial margin with row of long slender setae; outer lobe lateral margin with short setae, apical setae serrate, subapical setae slender.

MAXILLIPED (Fig. 13MXP). Inner lobe reaching distal end of article 1 of palp, distal end truncate with plumose setae along entire margin, medioproximal margin with long plumose setae, distolateral corner with fine setae; outer lobe almost reaching distal end of palp article 2, medial margin straight with long slender and robust setae, lateral margin convex with long fine setae on proximal half and short setae on distal half of margin; palp 4-articlulate, article 2 medial margin with long slender setae, article 3 spatulate, distal end with long slender and serrate setae, article 4 subtriangular, apically truncate ending in a stout spine.

GNATHOPOD 1 (Fig. 12G1). Larger than gnathopod 2, carpochelate; distal articles highly setiferous; coxa small, subquadrate; basis proximoposterior margin notched, posterior margin expanded and slightly convex, distoposterior margin with slender setae, anterior margin straight; ischium subquadrate, distoposterior margin with slender setae; merus subtriangular, distoposterior margin with row of slender setae; carpus enlarged, at least twice as long as propodus, dorsal margin convex, ventral margin straight with a row of short plumose setae and submarginal short setae, palm with processes forming a broad excavate sinus; propodus ventral margin produced, with long slender setae, dorsal margin with long plumose setae; dactylus falcate; subequal in length to propodus.

GNATHOPOD 2 (Fig. 12G2). Subchelate; distal articles highly setiferous; coxa subquadrate; basis slender, slightly expanding distally; ischium subquadrate; merus subquadrate, distal margin possessing long plumose setae; carpus slightly shorter than propodus; dorsal margin straight, ventral margin convex and lined with long plumose setae; propodus slender, dorsal margin possessing long plumose setae, inner face with transverse row of proximal long plumose setae, palmar margin denticulate, not defined by robust setae or spine, possessing submarginal robust setae; dactylus falcate, fitting palm.

PeREOPOD 3-4 (Fig. 14P3-P4). Coxae subhastate; basis anterior margin with short robust setae; ischium subquadrate, about 3 times as short as merus; merus expanding distally; carpus subovate, shorter than propodus; propodus slender; dactylus falcate, subequal in length to carpus.

PEREOPOD 5 (Fig. 14P5). Short; coxa posteriorly produced; basis broad, anterior margin with short robust setae; ischium subquadrate; merus longer than carpus, distal corners with long robust setae; carpus posterior margin with 3 robust setae; propodus slender, posterior margin with a row of robust setae, anterodistal corner with long setae; dactylus falcate.

PeReopod 6 (Fig. 14P6). Shorter than 7; coxa anteriorly produced; basis anterior margin with row of short robust setae, posterior margin with long plumose setae on distal half; ischium with slender setae on anterior margin; merus slender; carpus shorter than propodus with robust setae on dorsal and ventral margins; propodus long, expanding distally, dorsal margin with 6 robust setae, ventral margin with 3 robust setae, ventrodistal corner with clump of long slender setae; dactylus about 0.3 times as short as propodus.

Pereopod 7 (Fig. 14P7). Coxa small; basis anterior and posterior margins setiferous with long plumose setae; ischium subquadrate; merus slender posterior margin with 5 robust setae; carpus slender with many robust setae along entire length; propodus slightly expanding distally with robust setae along anterior and posterior margin, posterodistal corner with clump of long slender setae; dactylus falcate. 


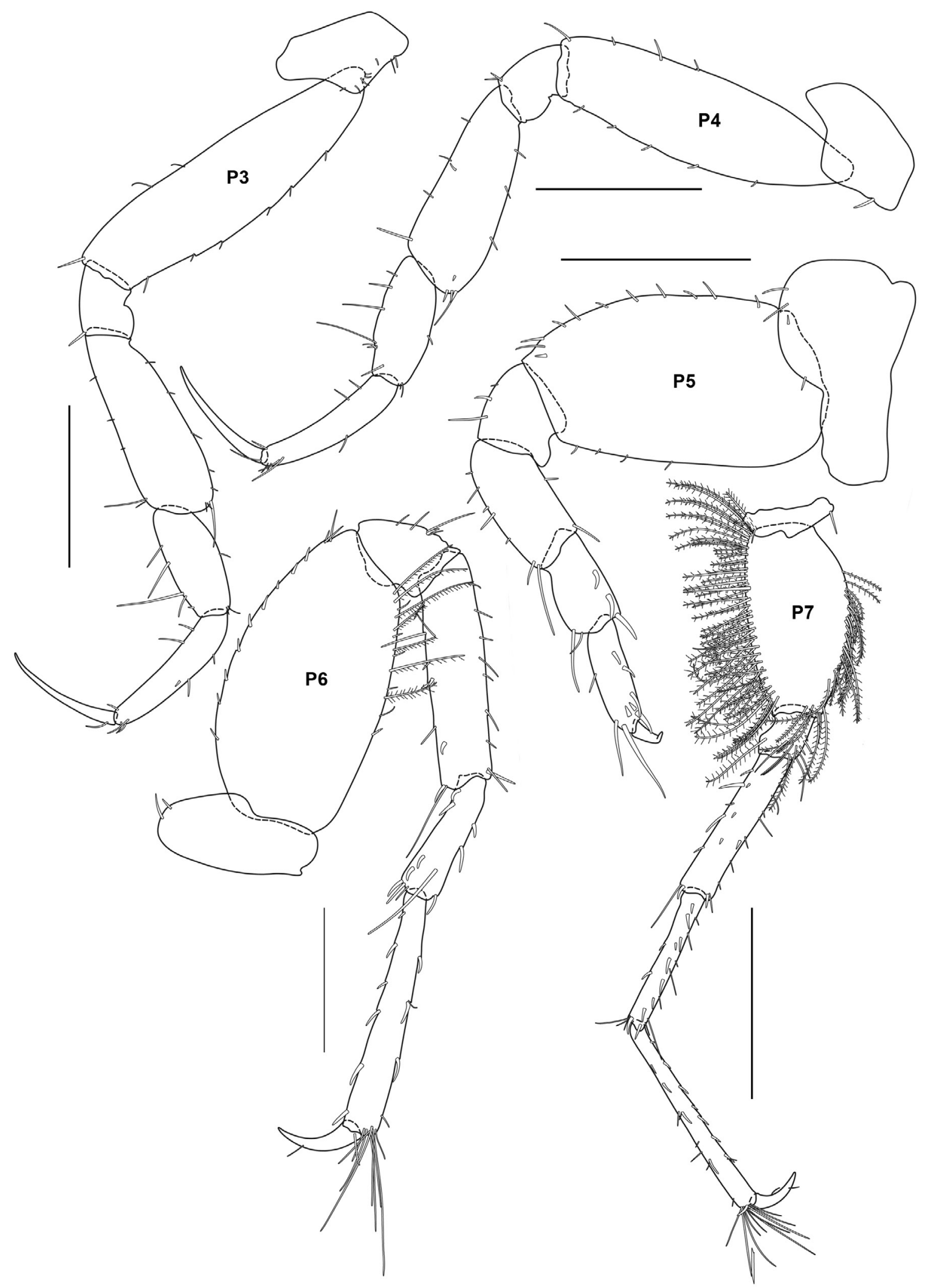

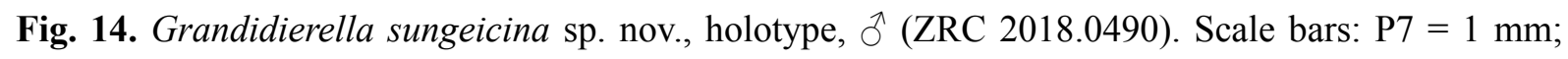
remaining scales $=0.5 \mathrm{~mm}$. 
UROPOD 1 (Fig. 15U1). Biramous, inner and outer rami subequal in length; peduncle longer than rami, lateral margin with 6 robust setae, inner margin with 4 robust setae, interramal spine present and shorter than peduncle; outer ramus lateral margin with 4 robust setae, medial margin with 2 robust setae, apice with 5 robust setae; inner ramus with 4 robust setae, apice with 4 robust setae.

UROPOD 2 (Fig. 15U2). Biramous; peduncle subequal in length to inner ramus, lateral margin with 2 robust setae, medial margin with 1 robust setae; outer ramus longer than inner ramus, lateral margin with 4 robust setae, medial margin with 2 robust setae, apice with 5 robust setae; inner ramus 1 marginal setae, apice with 5 robust setae.

URopod 3 (Fig. 15U3). Uniramous subquadrate, as broad as long, about 0.3 times as short as ramus; ramus 4 times as long as broad, lateral margin with 4 long robust setae, medial margin with 3 long robust setae, apice with 4 long robust setae.

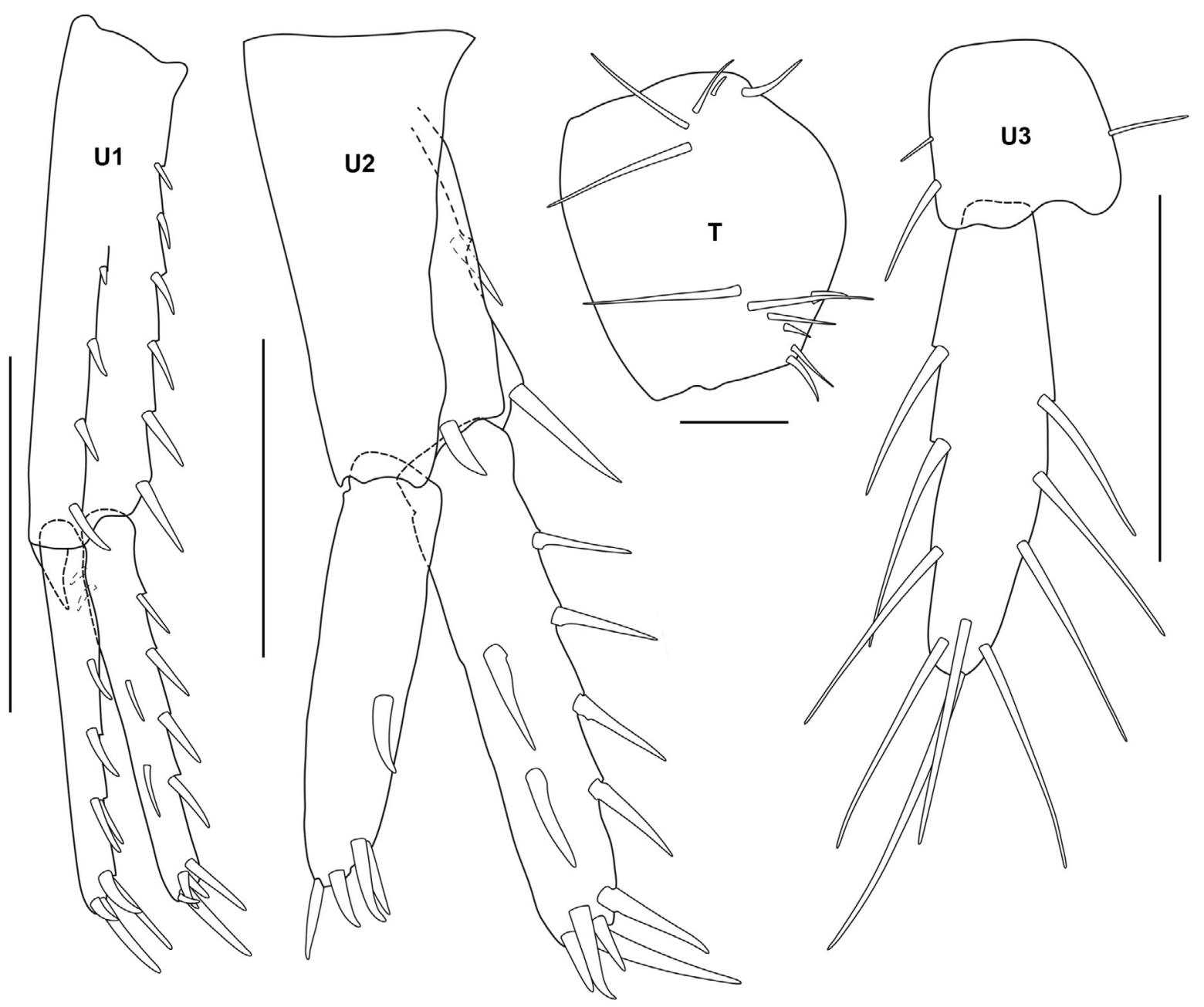

Fig. 15. Grandidierella sungeicina sp. nov., holotype, $\widehat{O}$ (ZRC 2018.0490). Scale bars: $\mathrm{T}=0.1 \mathrm{~mm}$; $\mathrm{U} 1=0.5 \mathrm{~mm}$; remaining scales $=0.25 \mathrm{~mm}$. 


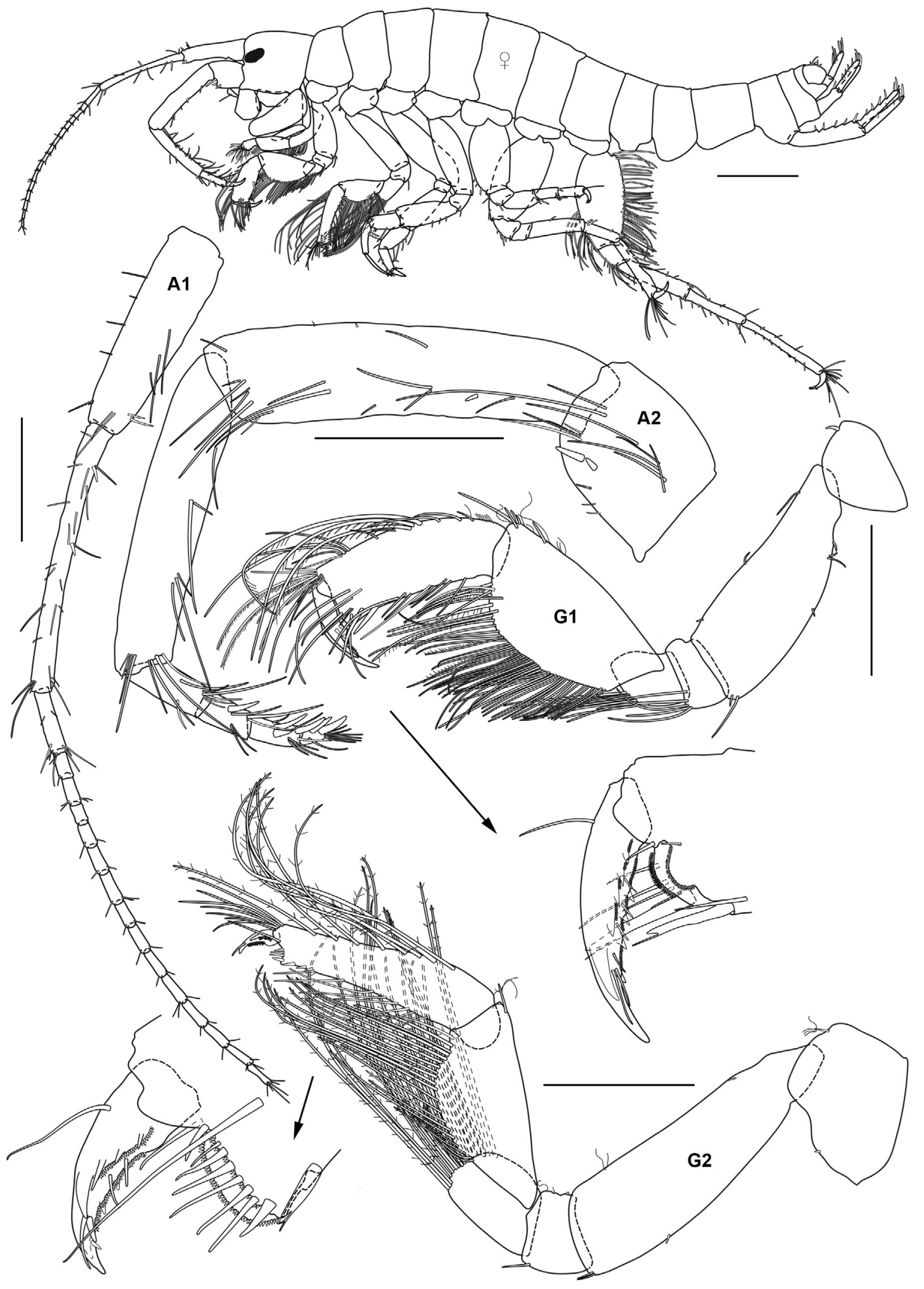

Fig. 16. Grandidierella sungeicina sp. nov., allotype, $q$ (ZRC 2018.0491). Scale bars: $0.5 \mathrm{~mm}$. 
TeLson (Fig. 15T). Entire, broader than long, distal margin convex, superficial face with long robust setae near median margin progressing to shorter setae near distal corners.

Female (dimorphic characters; based on the paratype + , ZRC 2018.0491)

GNATHOPOD 1 (Fig. 16G1). Subchelate; coxa subtriangular; basis slightly expanded posteriorly; ischium subquadrate, ventrodistal corner with long slender setae; merus subquadrate ventrodistal corner with long slender setae; carpus almost twice as long as broad, ventrally convex possessing serrate and slender

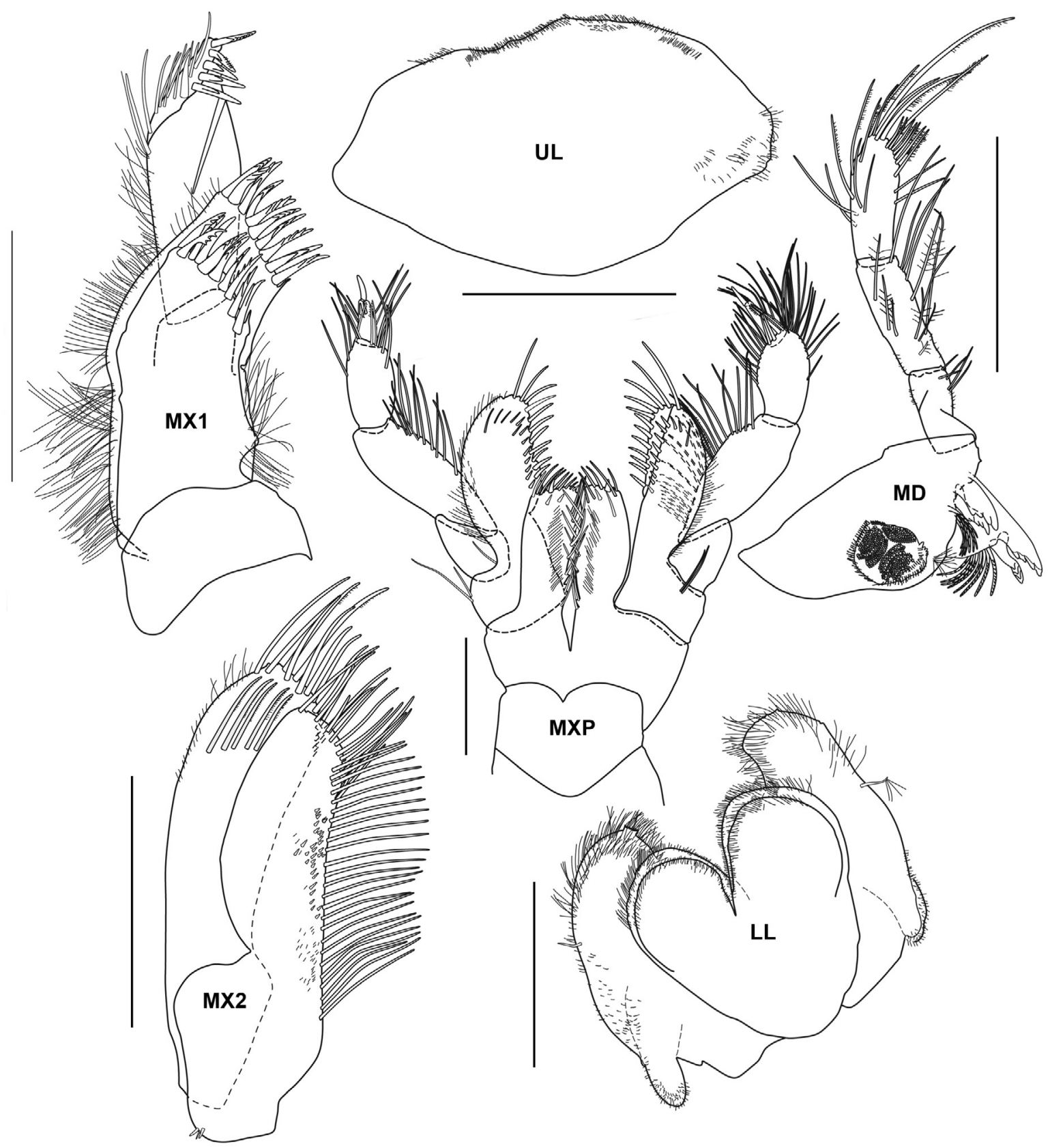

Fig. 17. Grandidierella sungeicina sp. nov., allotype, $q$ (ZRC 2018.0491). Scale bars: $\mathrm{MD}=0.5 \mathrm{~mm}$; remaining scales $=0.25 \mathrm{~mm}$. 


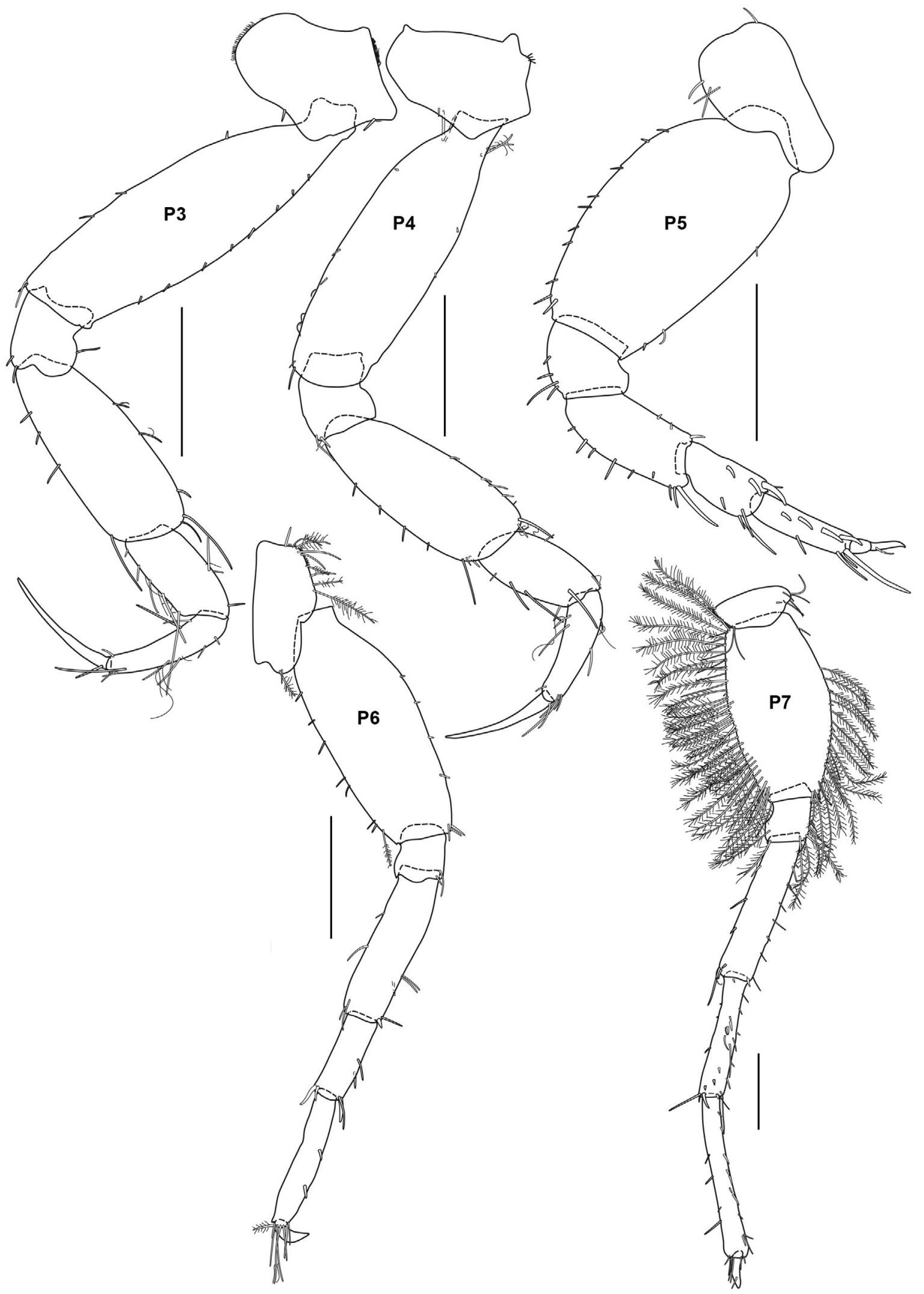

Fig. 18. Grandidierella sungeicina sp. nov., allotype, + (ZRC 2018.0491). Scale bars $=0.5 \mathrm{~mm}$. 
setae, dorsodistal corner with robust setae; propodus subequal in length to carpus, palm denticulate, margin defined by robust setae; dactylus falcate, doubly serrate, extending beyond palmar margin. Additional illustrations (Figs 17-19) are also provided for future reference.

\section{Remarks}

Grandidierella sungeicina sp. nov. is rather similar to illustrations made by Asari \& Myers (1982) and Ledoyer (1979) of G. gilesi. However, there is much morphological variation of the gnathopod 1 propodus. Both Asari \& Myers (1982) and Ledoyer (1979) showed no processes on the ventrodistal corner of the gnathopod 1 propodus, Chilton (1921) showed an apically acute process mid-margin while Myers (1981) had a blunt process. Grandidierella sungeicina sp. nov. on the other hand has an apically acute process. The new species also differs from $G$. gilesi wherein the merus of gnathopod 2 is distally truncate, instead of rounded, the ventral margin of the carpus is more convex and the inner face of propodus possesses a transverse row of long plumose setae instead of being oblique. Pereopod 6-7 coxae on the ventral margin do not possess plumose setae.

\section{Discussion}

The genus Grandidierella has a worldwide distribution with about five valid species have been reported from the South China Sea - G. gilesi: Thailand (Bussarawich et al. 1984); G. halophilus: Thailand (type locality); G. melakaensis: Malaysia (type locality); G. phetraensis: Thailand (type locality);
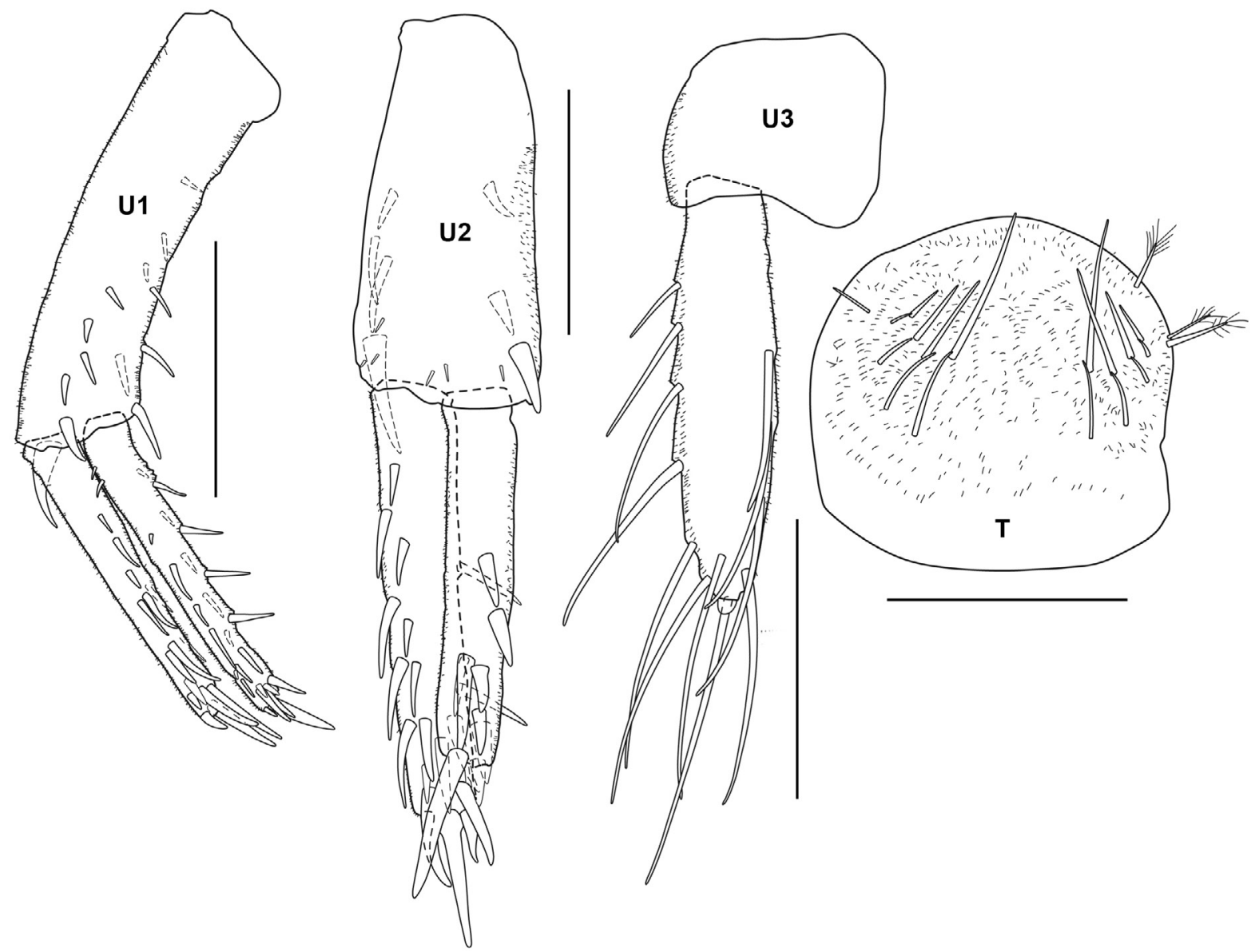

Fig. 19. Grandidierella sungeicina sp. nov., allotype, + (ZRC 2018.0491). Scale bars: $0.25 \mathrm{~mm}$. 
G. vietnamica: Vietnam (type locality). As of now, only two species of Grandidierella are known from the waters of Singapore. Both Grandidierella pawaiensis sp. nov. and G. sungeicina sp. nov. are described and illustrated in detail based on specimens collected from Pulau Pawai and Sungei Cina respectively. The characteristics of G. pawaiensis sp. nov. agree well with those of G. bispinosa in Ledoyer (1979) and Myers (1981) in: 1) flagellum of antenna 1 with a minimum of 11 articles; 2) carpus of gnathopod 1 large, with a single mediodistal tooth on inner face; 3 ) anterior margin of basis of gnathopod 2 crenulated; 4) strong interramal process of uropod 1 and; 5) uropod 3 with both one terminal and marginal seta each. However, it can easily be separated from both Ledoyer's (1979) and Myers' (1985) specimens by the following characters (characters of Ledoyer's and Myer's in parentheses): proximal margin of dactylus of gnathopod 1 male with excavation (without excavation and with fine setae along palm); peduncle of uropod 3 setulose anterodistally (not setulose). Grandidierella sungeicina sp. nov. on the other hand shares the diagnostic characters of G. gilesi, mainly in the structure of gnathopod 2. Based on the descriptions of G. gilesi by Asari \& Myers (1982) and Ledoyer (1979), however, G. sungeicina sp. nov. can be distinguished from these specimens by different morphologies of the gnathopod 1, carpus of gnathopod 2 with a more convex ventral margin, and the lack of plumose setae on the ventral margin of coxae 6-7.

Taking into account the two species described in this paper, the genus Grandidierella now comprises 46 species. A further examination of the shallow and deep benthic habitats of the Singapore coasts, could reveal more undescribed gammaridean amphipods. The finding of these two new species of Grandidierella in South East Asia considerably extends the distributional range of the genus. Species of the genus are now known from European-North American (Munari et al. 2016), African and East Asian waters, which suggests that the genus basically could be present anywhere in the world.

\section{Key to species of Grandidierella in the South China Sea (adult males)}

1. Uropod 1 peduncle lacking inter-ramal process ................ G. melakaensis Azman \& Othman, 2012

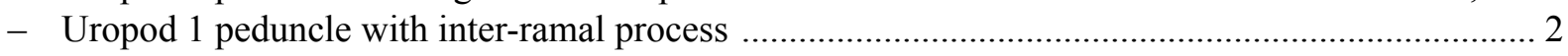

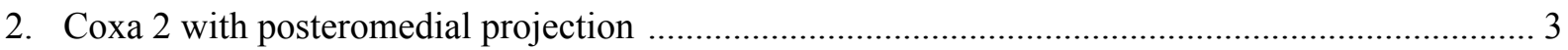

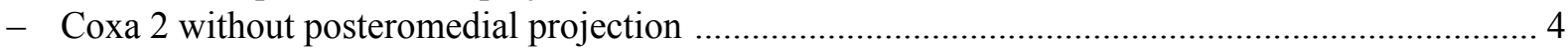

3. Gnathopod 1 basis slender (length ca 3.3 times of width)

G. halophilus Wongkamhaeng, Pholpunthin \& Azman, 2012

- Gnathopod 1 basis wide (length ca 2.0 times of width)

G. phetraensis Wongkamhaeng, Coleman, Pholpunthin, 2013

4. Gnathopod 1 carpus with stridulating ridges

G. vietnamica Dang, 1968

- Gnathopod 1 carpus without stridulating ridges

5. Gnathopod 2 basis anterior margin with crenulation G. pawaiensis sp. nov.

- Gnathopod 2 basis anterior margin without crenulation 6

6. Gnathopod 1 propodus with apical acute process

G. sungeicina sp. nov.

- Gnathopod 1 propodus without apical acute process G. gilesi Chilton, 1921

\section{Acknowledgments}

The authors would like to thank Asia Pacific Breweries Singapore, Care-for-Nature Trust Fund, Keppel Group, Shell Companies in Singapore and the Air Liquide Group for their generous support. We express our thanks to Wong Pei San Helen, Lee Yen-ling, Ria Tan, Toh Chay Hoon, Tay Ywee Chieh, Chen Chia Xin and all CMBS volunteers for assistance during the field trips. This study was also financed in part by 
the Ministry of Education (Malaysia) under the Fundamental Research Grant Scheme (FRGS/1/2019/ WAB13/UKM/02/3) to the senior author ABAR. The authors would also like to acknowledge the St. John's Island National Marine Laboratory under the National Research Foundation Singapore which enabled conducting the research.

Authors' contributions: AEA: conducted collecting trips, wrote the manuscript draft, descriptions and prepared line drawings. YL: conducted collecting trips, wrote the manuscript draft, descriptions and prepared line drawings. ABAR: provided generic identification, technical expertise, edited the draft, improved the taxonomic concept of the find, wrote the discussion and prepared the manuscript for the publication.

Competing interests: the authors declare that they have no competing interests.

Availability of data and materials: all material is deposited at the Lee Kong Chien Natural History Museum, National University Singapore (LKCHM NUS), Singapore.

Consent for publication: not applicable.

Ethics approval consent to participate: not applicable.

\section{References}

Asari K.P. \& Myers A.A. 1982. Taxonomic studies on the genus Grandidierella Coutière (Crustacea, Amphipoda) IV. Indian species. Bulletin du Muséum national d'histoire naturelle 4 (4): 237-256.

Azman B.A.R. \& Alip E.A. 2015. First record of Parelasmopus setiger Chevreux, 1901 from Singapore, including synonymization of Parelasmopus siamenses Wongkamhaeng, Coleman \& Pholputhin, 2013 with Parelasmopus setiger (Crustacea, Amphipoda, Maeridae). Zoosystematics and Evolution 91 (1): 59-70. https://doi.org/10.3897/zse.91.9014

Bussarawich S., Nateewathana A. \& Hylleberg J. 1984. Distribution of marine benthic amphipods off Phuket Island, with emphasis on tin mining and a model of species-individual relationships. Phuket Marine Biological Center Research Bulletin 32 (1): 1-21.

Chilton C. 1921. Amphipoda fauna of the Chilika Lake. Memoirs of the Indian Museum 5: 519-558.

Coleman C.O. 2003. "Digital Inking": how to make perfect line drawings on computers. Organisms Diversity \& Evolution 3 (4): 303-304. https://doi.org/10.1078/1439-6092-00081

Ledoyer M. 1979. VI. Crustacés amphipodes gammariens. In: Monod T. \& Serene R. (eds) Expédition Rumphius II (1975). Crustacés parasites, commensaux, etc. Bulletin du Muséum national d'histoire naturelle 4 (1): 137-181.

Lowry J.K. 2000. Taxonomic status of amphipod crustaceans in the South China Sea with a checklist of known species. The Raffles Bulletin of Zoology Supplement 8: 309-342.

Mayer P. 1903. Die Caprellidae der Siboga-Expedition. Siboga-Expedition Monographs 34: 1-160.

Munari C., Bocchi N. \& Mistri M. 2016. Grandidierella japonica (Amphipoda: Aoridae): a nonindigenous species in a Po delta lagoon of the northern Adriatic (Mediterranean Sea). Marine Biodiversity Records 9: 12. https://doi.org/10.1186/s41200-016-0018-5

Myers A.A. 1981. Taxonomic studies on the genus Grandidierella Coutière (Crustacea, Amphipoda) Part 3: Fijian, Australian and Arabian Species. Bulletin du Muséum national d'histoire naturelle 4 (3): 213-226. 
Myers A. A. 1985. Shallow-water, coral reef and mangrove Amphipoda (Gammaridea) of Fiji. Records of the Australian Museum 5: 1-143.

Schellenberg A. 1938. Litorale Amphipoden des tropischen Pazifiks nach Sammlungen von Prof. Bock (Stockholm), Prof. Dahl(Berlin) und Prof. Pietschmann(Wien). Kungliga Svenska Vetenskapsakademiens Handlingar, Series 3, 16: 1-105.

Stebbing T.R.R. 1887. On some new exotic Amphipoda from Singapore and New Zealand. The Transactions of the Zoological Society of London 12: 199-210.

https://doi.org/10.1111/j.1096-3642.1887.tb00013.x

Watling L. 1989. A classification system for crustacean setae based on the homology concept. In: Felgenhauer B.E., Watling L. \& Thistle A.B. (eds) Functional Morphology of Feeding and Grooming in Crustacea. Crustacean Issues 6: 15-27. Balkema, Rotterdam.

White K.N. 2015. A checklist of Amphipoda (Crustacea) collected from the mudflats of Pulau Ubin, Singapore. The Raffles Bulletin of Zoology Supplement 31: 139-142.

Manuscript received: 7 April 2020

Manuscript accepted: 3 June 2020

Published on: 9 July 2020

Topic editor: Rudy Jocqué

Desk editor: Pepe Fernández

Printed versions of all papers are also deposited in the libraries of the institutes that are members of the EJT consortium: Muséum national d'histoire naturelle, Paris, France; Meise Botanic Garden, Belgium; Royal Museum for Central Africa, Tervuren, Belgium; Royal Belgian Institute of Natural Sciences, Brussels, Belgium; Natural History Museum of Denmark, Copenhagen, Denmark; Naturalis Biodiversity Center, Leiden, the Netherlands; Museo Nacional de Ciencias Naturales-CSIC, Madrid, Spain; Real Jardín Botánico de Madrid CSIC, Spain; Zoological Research Museum Alexander Koenig, Bonn, Germany; National Museum, Prague, Czech Republic. 